Dario Pozzoli

The Transition to Work for Italian University Graduates

Department of Economics 


\title{
The Transition to Work for Italian University Graduates
}

\author{
Dario Pozzoli* \\ Aarhus School of Business, Denmark
}

April 18, 2008

\begin{abstract}
This study investigates the hazard of first job for Italian graduates. The analysis is in particular focused on the transition from university to work, taking into account the graduates' characteristics and the effects relating to degree subject. It is used a large data set from a survey on job opportunities for the 1998 Italian graduates. The paper employs a non parametric discrete-time single risk models to study employment hazard. Alternative mixing distributions have also been used to account for unobserved heterogeneity. The results obtained indicate that there is evidence of positive duration dependence after a short initial period of negative duration dependence. In addition, competing risk model with unobserved heterogeneity and non parametric baseline hazard have been estimated to characterize transitions out of unemployment.
\end{abstract}

JEL Classification: J64; C41; C50.

Key words: discrete time survival model; unobserved heterogeneity, competing risk model.

\footnotetext{
* Corresponding Author Address: Department of Economics, Aarhus School of Business, Prismet, Silkeborgvej 2, DK-8000 Aarhus C, Denmark. Email: dpozzoli@asb.dk. I thank Lorenzo Cappellari, Michael Rosholm, Peter Jensen, Michael Lechner and Pierpaolo Parrotta for comments and an anonymous referee for very useful suggestions. Financial support from the Aarhus School of Business is gratefully acknowledged. All errors are my own responsibility.
} 


\section{Introduction}

The problem of high unemployment rates for young people has been featuring top of public policy discussion and of government policy-making in Italy in recent years. The difficulties of getting a job for young people are so relevant that we can consider youth unemployment as a distinct and stable feature of Italian unemployment. The outstanding youth unemployment incidence constitutes a common element of Southern European labour markets. In Italy, youths of age between 15 and 24 years represent about $30 \%$ of the total population searching for a job in 1999. This situation is comparable only to the other Mediterranean countries (Spain and Greece). The peculiarity of the Italian situation is stressed by the fact that even in countries where the general unemployment rate is close to the Italian one (France), the youth unemployment incidence is much lower $(22 \%)^{1}$. Another important feature of Italian youth unemployment is that it is above all concentrated among women and in the South. As a matter of fact, considering the age group from 15 to 24 years, female unemployment is $35 \%$ higher than the male one and the youth unemployment rate in the Southern regions is almost three times as much as the one in the North of Italy ${ }^{2}$. Moreover, the youth unemployment rate increases among the youths with a university degree. In particular the university graduates face high unemployment rates especially in the first years after graduation ${ }^{3}$. This is not true if we consider high school graduates who have more chances of getting the first job, mainly in the Northern regions. This suggests that the transition from school to work has become more difficult and prolonged for individuals who get high levels of education ${ }^{4}$. Could these difficulties be explained by the fact that the Italian educational system produces a lot of university graduates? The answer, in this case, is negative because Italy is one of the countries where the percentage of university graduates is the lowest $(8 \% \text {, in } 1995)^{5}$. The most plausible explanations for the difficult transition from university to work of Italian graduates are, among the others: i) possible mismatch between labour demand and supply; ii) excessive insiders' protection and new entrants' relegation to temporary jobs; iii) shortages of incentive and flexible active labour market policies targeted to youth unemployment; iv) insufficient economic growth with a limited occupational content; v) manufacturing system based on non-innovative small and middle-sized firms demanding more frequently technical and executive staff than personnel with high education.

The experience of these new entrants into the labour market differs substantially, however, among individuals. Some take longer to get a job than others. The reasons for these differences are worth exploring since the early labour market experience of school

\footnotetext{
${ }^{1}$ Source: Censis, Rapporto sulla situazione del Paese, anno 1999.

${ }^{2}$ Source: elaborazioni su dati ISTAT, rilevazione delle forze lavoro, primo trimestre 1999.

${ }^{3}$ The unemployment rate of university graduates two years and 5-6 years after graduation are respectively $27 \%$ and $13.3 \%$ (Source: ISTAT, rapporto annuale 1998 ).

${ }^{4}$ In the early nineties almost $80 \%$ of university graduates were employed 3 years after graduation. The same percentage has descreased to $67 \%$ in 1995 and to $72 \%$ in 1998 .

${ }^{5}$ The same percentage for US and UK are respectively $24 \%$ and $12 \%$ (Source OCSE, Regard sur l'education 1997).
} 
leavers can have long-lasting effects on subsequent lifetime outcomes. The previous research has shown that school leavers entering the labour market who take longer to get a job have higher future probability of being unemployed and are more likely to have lower future earnings. Several studies, for example, show that both the incidence and duration of unemployment adversely affect the future probability of being in a job (Narendranathan and Elias; 1993; Omori 1997; Mroz and Savage 1999; Arulampalam et al; 2000). More importantly for school leavers is the fact that duration of time-tofirst-job adversely affects subsequent employment outcomes (Margolis et al; 1999).

The problems of youth labour market highlighted previously explain why the analysis of the transition from university to labour market has received increasing attention in the labour micro-econometric literature. The recent work has focused mostly on issues such as the ease and speed of transitions into jobs, the process of job search, the relationship between the degree course and the skills needed in the jobs held, and the determinants of graduates pay. Papers that I'm aware of include Tronti and Mariani (1994), Checchi (2001), Staffolani and Sterlacchini (2001), Vitale (1999), Ghirardini and Pellinghelli (2000), Brunello and Cappellari (2007) and Makovec (2005). Generally these papers analyse data on individual students from particular universities (or university regions).

However very few studies investigate explicitly the problem of the time to obtain the first job. These exceptions are based on survival analysis, as this can deal with the censoring and truncation problems ${ }^{6}$ easily through appropriate specification of the sample likelihood and can handle time-varying covariates reorganizing appropriately the data set. The methods commonly used in economics (Ordinary Least Squares regressions of survival times or binary dependent variable regression models with transition event occurrence as the dependent variable) cannot be applied in this context.

The work by Santoro and Pisati (1996) employs a continuous survival time Cox model, using a sample of students who graduated in 1993 from one of the universities of the Emilia-Romagna Region. They found that family background, high school type, university region, work experience while at university and age at the date of the degree don't impact on the time needed to obtain the first job. On the other hand, the specific course programme attended has a significant effect on the hazard of getting a job: Economics and Engineering are better than Law and Humanities. Santoro and Pisati also found that the hazard of employment is negatively correlated with the degree score: the most brilliant students are more likely to go on to further education (master, phd etc...) or are choosy about proposed job opportunities. Contrary to mine, this study however does not explicitly take into account unobserved heterogeneity between graduates. Many analyses (Lancaster, 1979; Nickell, 1979; Lynch, 1985) have emphasized the importance of incorporating unmeasured heterogeneity into the specification of the distribution for unemployment duration because unmeasured heterogeneity leads to

\footnotetext{
${ }^{6}$ Whereas censoring means that we don't know the exact length of a completed spell in total, truncation refers to whether or not we observe a spell or not in our data (sample selection on dependent variable). It is possible to distinguish two types of censoring (left and right censoring) depending on whether we don't observe the spell start date or the spell end date. We may distinguish also two types of truncation (left and right truncation) in relation to the survival time data collection method.
} 
biased inference in duration models.

Biggeri, Bini and Grilli (2000) evaluate the effectiveness of educational institutions with respect to job opportunities using a multilevel discrete time survival model. The paper tackles the problem, analysing a large data set (13511) from a survey on job opportunities for the 1992 Italian graduates conducted by ISTAT in 1995. The graduates are nested in course programmes which are grouped into universities, so that data set has a hierarchical three-level structure. It is estimated a multilevel version of the discrete time model by introducing random effects at course programme and university level (in particular a three level discrete time survival model where the logit of the hazard conditionally on the normal random effects is a linear function of the covariates). The individuals do not constitute a level in this structure because the hypothesis of normal unobserved heterogeneity between graduates was not supported by the data. They found that the hazard of obtaining the first job is monotonically decreasing in time and that the universities in the North of Italy are the most effective with respect to job opportunities. They also saw that there is an important gender differences in favor of males which is more pronounced for graduates with low final marks and that the final mark has a positive effect but of low magnitude. This paper however imposes very restrictive parametric assumptions both on duration dependence ( third order polynomial of time) and on unobserved heterogeneity at different levels (normality). The early empirical social science literature found that conclusions about whether or not unobserved heterogeneity was important (effects on estimate of duration dependence and estimates of the other coefficients) appeared to be sensitive to choice of shape of distribution and that the choice of distributional shape was essentially arbitrary. This stimulated the development of non-parametric methods. Moreover subsequent empirical work suggests that the effects of unobserved heterogeneity are mitigated if the analyst uses a flexible baseline hazard specification. Contrary to Biggeri et al, in the present paper I will take into account these considerations by assuming a non parametric specification for duration dependence and by trying different specification for individual unobserved heterogeneity distribution (gamma and discrete).

Hence the purpose of this paper is to extend the current literature based on Italy's data by appropriately incorporating individual unobserved heterogeneity into the econometric specification and using a flexible baseline hazard specification to study the factors that determine the transition from university to work as well as to evaluate the effectiveness of university and course programmes with respect to the labour market outcomes of their graduates. The results obtained indicate that there is a general evidence of true positive duration dependence after a short initial period of negative duration dependence with and without unobserved heterogeneity and under a non parametric specification for the baseline function. According to Biggeri et al paper instead, the longer university leavers stay unemployed, the less likely they are to become employed. This negative duration dependence, however, may be a result of unobserved heterogeneity (weeding out effect), which is not appropriately controlled for, as I mentioned above. The true positive duration dependence could be explained by the fact that university graduates tend to be choosier with respect to job opportunities in the first quarters after graduation. As time proceeds, they become less selective because 
they (feeling either discouraged or desperate) adjust their search effort and methods over the course of a given spell: an individual may look initially only into the best jobs available for a person with his or her skills, but look into less desirable opportunities later in a spell. Another possible explanation for true positive duration could be that during the unemployment spell, university graduates get more and more informed on where and which job opportunities are available and this increased search ability influences positively the hazard of getting the first job. Very similar results are obtained using the 2004 wave of the graduates' employment survey.

With regards to the effects of covariates, older and female graduates, those who graduated in Humanities and Social Sciences, those who have parents with the lowest level of education and finally those who live in Southern and Central Italy are found to have particularly lower hazard of getting their first job. Sensitivity analysis indicate that there is some heterogeneity in the results by gender and by macro-regions.

Another novelty of this paper with respect to the previous works resides in its identification of 2 destination states, namely, open-ended employment and fixed-term contracts. Results from competing risk model reveal that the use of an aggregate approach sometimes compound distinct and contradictory effects. Thus, for example, the probability of finding employment in open-ended contracts is increasing with the level of education of parents. But these effects are completely absent if we consider exits to fixed-term contracts. Female graduates have a higher hazard of exit to fixed contracts but a lower hazard of exit to open-ended employment compared to their male counterparts. Those who live in the Centre of Italy are less likely to enter open-ended employment than their Northern Italian counterparts, this is not true if we consider exit to fixed term contracts.

This study has five parts and has the following structure. Section 2 is devoted to the description of the data and sample used in the empirical exercise carried out in this study. Section 3 gives an account of the econometric specifications and methods of estimation used for the purpose of studying the time to first job. Section 4 discusses the estimation results obtained and the final section concludes the paper.

\section{Data}

In 2001, the National Statistical Institute (ISTAT) conducted the fourth survey on the transition of Italian graduates into the labour market. The objective of the survey is to analyse the occupational position of graduates three years after the completion of their university studies. Accordingly, the 2001 survey is conducted on those graduating in 1998. The graduate population of 1998 consisted of 105,097 individuals (49,393 males and 55,704 females). The ISTAT survey was based on a $25 \%$ sample of these students and was stratified on the basis of university attended, degree course taken and by sex of the individual student. The response rate was around $60 \%$, yielding a data-set containing information on 20,844 graduates. The data contains information on: the curriculum studied up to graduation in 1998, the occupational status and related work 
details by 2001, the search processes of successful leavers used between 1998 and 2001, the student's family background and personal characteristics.

For the present analysis, the sample of 20,844 records is reduced to 16,195 records by eliminating the individuals who: (i) started their current jobs while at university, since their post-graduation choices might be not comparable with those of the rest of the sample; (ii) declared that they were not interested in finding a job.

In this paper, the object of interest is the time to obtain the first job. The latter is grouped in quarters, because the survey indicates only the quarter of graduation and not its precise month. Here, it is possible to distinguish between temporary and permanent jobs, but information on the contract type (part-time, full-time) is not provided. The questionnaire allows us to make the latter classification only with respect to the job held at the date of the interview, which is not necessarily the first job. The graduates in 1998 were interviewed in December 2001, so the observable time to obtain their first job ranges from 1 to 16 quarters. The time for the graduates who were still unemployed at the date of interview is right censored and assumes a value between 12 and 16 depending on the quarter in which the individuals received their degree. Table 1 reports the distribution of Italian graduates according to the duration of unemployment prior to the first job. Results show that $34 \%$ of school leavers obtain a first job 3 quarters after completion of university, 25\% are unemployed for 4 to 7 quarters, and about $27 \%$ are still unemployed 11 quarters after leaving university. Analysis by gender indicates that among young men and women differences in length of unemployment are large: women are less likely than men to find a job 3 quarters after completing formal schooling (32\% vs 37\%), and they are much more likely to be still unemployed 11 quarters after leaving the education system (32\% versus $22 \%$ ).

Although I am estimating reduced-form models of Italian graduates' transition from university to work, the classical job search model can be useful in motivating the explanatory variables used. This model focuses on duration dependence and the income flow while unemployed, so it is natural to have elapsed spell duration and some proxies of family income (parents' education) among my explanatory variables. Some measure of the local unemployment rate and of the labour market networks available to graduates enable me to evaluate the arrival rate of new jobs, that's why I use some geographical variables as proxy for local labour market conditions and the father's occupation as a proxy for networks. Similarly, I have also to find some pre-determined measure of individuals' past education (type of high school, degree subject, scores) and work experience (seasonal or occasional occupations during university) since this impacts on human capital as well as measuring attachment to the labour force. Unfortunately, the dataset lacks something like the wage distribution used in the job search model to measure employment prospects.

The definitions of covariates used in the analysis are reported in the appendix A along with their sample means. Concerning the covariates the following clarifications should be made : (1) there are not time-varying covariates; (2) the dummy variable "military service" simply indicates whether the service was done after the degree as opposed to either being done before the degree or that the student was exempted from it. Actually, the starting date of military service is unknown, but this lack of 
information is not a serious problem here since military service was 1 year long, with the possible call occurring within 1 year after graduation; hence a military service covariate equal to 1 indicates that the service started and ended within the observation period of the survey, thus controlling for a definitely prior event. I added this variable to control for the fact that those graduates who did their military service after graduation were temporarily out the labour force and they had, for this reason, a disadvantage in the speed of transition to first job compared to the other male graduates; (3) the sample employed in the analysis has 15 fields of study which I have further grouped into 4 main categories ${ }^{7}$ : Scientific, Engineering, Humanities, Social Sciences; from table 1 we can see that graduates in scientific subjects represent nearly $22.75 \%$ of the whole sample, while graduates in Engineering and Social sciences constitute $19.25 \%$ and $33.97 \%$ respectively. Finally those who graduated in Humanities consist in only $24.03 \%$; (4) the geographical dummies refer to the University regions; (5) the dummy "mobility" indicates whether the student transferred to another region to attend university; (6) parental background is described by 7 categorical variables summarizing both parents' educational level and by father's occupation; as we can see from table 4 there is no clear correlation between unemployment spells and parental education; (7) as indicator of academic performance I used the variable "final mark" (ranging from 66 to 110). The distribution of final mark is highly right skewed. This suggest that there is a ceiling effect which weakens the correctness of this covariate as an indicator of academic ability. To compensate partially for the previously mentioned deficiencies of the final mark, I used also, as measures of ability, a dummy referred to whether or not the individual took the degree in the institutional time, the score at high school and the type of high school (general, vocational/technical or other).

\section{Model Specifications and Methods of Estimation}

The fact that the duration variable of interest (time to obtain the first job) is measured in quarters means that the appropriate approach to modeling the duration of unemployment is the discrete-time hazard model. The estimation of discrete-time duration models requires expanded or person-period data set organized in such a way that there will be as many data rows for each individual in the sample as there are time intervals over which the individual in question is at risk of experiencing the event of interest (Jenkins 1995, 1997)- first job here. Following Meyer (1990), the discrete time hazard of exiting the state of unemployment can be modeled using the discrete-time proportional hazards model. In particular, the hazard of employment in the jth quarter, $\mathrm{h}\left(\mathrm{t}_{j}\right)$, for individual $\mathrm{i}$ with a vector of covariates, $\mathrm{x}$, having spent $\mathrm{t}$ quarters in unemployment and given that employment has not occurred before $t_{j-1}$ can be given by:

${ }^{7}$ The grouping in particular is the following: Scientific (chemistry, pharmacy, biology, agricultural, geology); Engineering (engineering, architecture); Social sciences (political sciences, sociology, law, economics and statistics); Humanities (literature, foreign languages, psychology, pedagogy). 


$$
h_{i j}=1-\exp \left(-\exp \left(\gamma_{j}(t)+\left(x_{i} \beta\right)\right)\right), \text { where } \gamma_{j}(t)=\int_{-\infty}^{\infty} h_{o}(u) d u
$$

$\gamma_{j}(t)$ represents the baseline hazard which can be specified either parametrically or semi-parametrically. I have assumed a non parametric specification ${ }^{8}$. Rearranging (1) gives what is known as the complementary log-log transformation of the conditional probability of exiting the state of unemployment at time $t_{j}$ as:

$$
\ln \left(-\ln \left(1-h_{i j}\left(t_{j} \mid x_{i}\right)\right)\right)=x_{i}^{\prime} \beta+\gamma_{j}(t)
$$

Given this complementary log-log transformation, the parameter $\beta$ is interpreted as the effect of covariates in $\mathrm{x}$ on the hazard rate of employment in interval $\mathrm{j}$, assuming the hazard rate to be constant over the $\mathrm{j}_{t h}$ interval.

Assuming that we observe a person i's spell from quarter $\mathrm{k}=1$ through the end of the jth quarter, at which point i's spell is either complete $\left(c_{i}=1\right)$ or right censored $\left(c_{i}=0\right)$, the log likelihood function for the whole sample can be written as:

$$
\log L=\sum_{i=1}^{n} c_{i} \log \left(\frac{h_{i j}}{1-h_{i j}}\right)+\sum_{i=1}^{n} \sum_{k=1}^{j} \log \left(1-h_{i k}\right)
$$

Defining a new binary indicator variable $\mathrm{y}_{i k}=1$ if person $\mathrm{i}$ makes a transition in quarter $\mathrm{k}$, and $\mathrm{y}_{i k}=0$ otherwise allows the likelihood function to be rewritten as:

$$
\log L=\sum_{i=1}^{n} \sum_{k=1}^{j} y_{i k} \log h_{i k}+\left(1-y_{i k}\right) \log \left(1-h_{i k}\right)
$$

It is well established in the duration literature that not accounting for unobserved heterogeneity might lead to biased estimates of the baseline hazard as well as the covariate effects on the hazard of exit from the state of unemployment (Lancaster, 1979, Heckman and Singer, 1984a; Heckman and Singer, 1984b; Van den Berg, 2001). Taking this into account, an attempt has been made in this study to control for unobserved heterogeneity ${ }^{9}$. The standard practice in the literature is to introduce a positivevalued random variable (mixture), $\mathrm{v}$, into the hazard specification. In the context of

\footnotetext{
${ }^{8}$ Each interval has different baseline hazard.

${ }^{9}$ The unobserved individual characteristics are usually referred to as "frailty" in the bio-medical sciences.
} 
the proportional hazard approach, the augmented hazard function, which incorporates a multiplicative mixture term, is given by:

$$
\ln \left(-\ln \left(1-h_{i j}\left(t_{j} \mid x_{i}\right)\right)\right)=x_{i}^{\prime} \beta+\gamma_{j}(t)+u_{i}
$$

where $\mathrm{u}_{i}=\log \left(\mathrm{v}_{i}\right)$. It is not possible to estimate the values of $\mathrm{v}$ themselves since, by construction, they are unobserved. However if we suppose that the distribution of $\mathrm{v}$ has a shape whose functional form is summarized in terms of only a few key parameters, then it is possible to estimate those parameters with the available data. So after having specified a distribution for the random variable v, we derive the "frailty" survivor corresponding to this mixture distribution and we write the likelihood function so that it refers to the original parameters and mixing distributional parameters rather than each $\mathrm{v}^{10}$. The unobserved heterogeneity term is assumed to be independent of observed covariates, $\mathrm{x}_{i}$, and the random duration variable, $\mathrm{T}$, and has density . In the absence of theoretical justification ${ }^{11}$ for using one or the other approach, I assume two alternative distributions: gamma ${ }^{12}$ and discrete $^{13}$.

Finally I have also distinguished between two exit modes out of unemployment (fixed-term contracts and open-ended contracts) estimating an independent competing risks model. Hence I have defined the cause-specific hazard function to destination fc (fixed contracts) and to destination oc (open-ended contracts) as:

$$
\begin{aligned}
& h_{i j}^{f c}=1-\exp \left[-\int_{t_{j-1}}^{t_{j}} \theta_{f c}(t) d t\right] \\
& h_{i j}^{o c}=1-\exp \left[-\int_{t_{j-1}}^{t_{j}} \theta_{o c}(t) d t\right]
\end{aligned}
$$

\footnotetext{
${ }^{10}$ This is known as "integrating out" the random individual effect.

${ }^{11}$ However, Abbring and van den Berg (2007) show that in duration models the heterogeneity distribution usually converges to a Gamma distribution.

${ }^{12}$ If v has a Gamma distribution with unit mean and variance $\sigma^{2}$, as proposed by Meyer (1990), there is a closed form expression for the frailty survivor function used to calculate the sample likelihood.

${ }^{13}$ The non-parametric approach pioneered by Heckman and Singer (1984b) characterizes the frailty distribution as a discrete distribution defined by a set of "mass points" along the support and corresponding probabilities of being located at each of these points. The position and probability of each mass point is determined from the data themselves, conditional on the number of mass points chosen by the researcher (typically, one starts off with two mass points and can then try to increase their number, although convergence is usually only achieved with a small number of mass points). Each mass point can be interpreted as an estimated fixed effect for a group of people who share a certain unobserved ceteris paribus propensity to make the corresponding transition, and the probability of each mass point as the estimated share of the sample with this specific propensity. I have chosen to estimate the model with two mass points, because setting three or four mass points does not give a higher maximized log-likelihood.
} 
where $\theta_{f c}$ and $\theta_{o c}$ are the underlying destination-specific continuous time hazard. The overall discrete hazard and the survivor function for exit to any destination for $\mathrm{t}_{j}$ are instead given by:

$$
\begin{gathered}
h_{i j}=1-\left\{\left[1-h_{i j}^{f c}\right]\left[1-h_{i j}^{o c}\right]\right\} \\
S_{i j}=S_{i j}^{f c} S_{i j}^{o c}
\end{gathered}
$$

To proceed further, I make the assumption that transitions can only occur at the boundaries of the intervals ${ }^{14}$. Then the overall likelihood contribution for the person with a spell length $t_{j}$ is given by:

$$
L_{i j}=\left(L_{i j}^{f c}\right)^{\delta_{f c}}\left(L_{i j}^{o c}\right)^{\delta_{o c}}\left(L_{i j}\right)^{1-\delta_{f c}-\delta_{o c}}=\left[\frac{h_{i j}^{f c}}{1-h_{i j}^{f c}}\right]^{\delta_{f c}} S_{i j}^{f c}\left[\frac{h_{i j}^{f c}}{1-h_{i j}^{f c}}\right]^{\delta_{f c}} S_{i j}^{o c}
$$

where $\delta_{f c}$ and $\delta_{o c}$ are the destination-specific censoring indicators. Thus the likelihood contribution (4) partitions into a product of terms, each of which is a function of a single destination-specific hazard only. Consequently, it is possible to estimate the overall independent competing risk model by estimating separate destination-specific models having defined suitable destination-specific censoring variables. As in the previous model, also in the competing risks one I have accommodated the presence of observed individual heterogeneity assuming a multiplicative error term associated with each specific hazard function. I further assume that the errors are gamma distributed with mean 1 and variance $\sigma^{2}$.

\section{Estimation Results and Discussion}

In this section discussion of results from estimation will be made. The first set of results in this study is that which is based on non-parametric duration analysis, the second set is from single risk duration models with unobserved heterogeneity. The third set of results is from independent competing risk models with unobserved heterogeneity. Finally I show sensitivity analysis of the main results.

\footnotetext{
${ }^{14}$ The assumption may not be an appropriate one in practice. So I have also estimated a multinomial logit model, originally developed for intrinsically discrete data. If the interval hazard rate was relatively small, this model may provide estimates that are a close approximation to a model for grouped-data with the assumption that the (continuous) hazard is constant within intervals.
} 


\subsection{Non-parametric Duration Analysis}

In the non-parametric approach to the duration analysis I provide the estimates of the Life-table's survivor and hazard functions ${ }^{15}$. They are the generalization of the Kaplan-Meier survivor and hazard functions for interval-censored data. Figure 1 and 2 give the plots of the aggregate and disaggregated (by subject groups) Life-table's survivor functions. The survivor function shows the proportion of people who survive unemployment as time proceeds. The graph imply that graduates in Humanities have the longest unemployment durations, followed by graduates in Social Sciences. The survivor functions for graduates in Engineering and in Scientific subjects decline more steeply than graduates from other groups implying that graduates in Engineering/Scientific subjects find jobs sooner than graduates in other subjects. The figure also implies that for graduates in Humanities, Social sciences, Scientific subjects and Engineering the probabilities of surviving beyond 10 quarters are respectively: 0.40 , $0.33,0.28,0,21$.

Figure 3 and 4 provide the plots of the aggregate and disaggregated hazard functions. As we can see from the graph for all data, the hazard rate increases over the quarters. If we look at the results for different subject groups, we observe that the hazard for graduates in engineering is larger than that for graduates in other groups until about the 15th quarter.

The null hypothesis of equality of survivor functions for different groups is rejected by both the log-rank and Wilcoxon tests ${ }^{16}$. Hence these statistics confirm that the survival functions for graduates from the 4 university groups are significantly different at any reasonable confidence level for duration to first job. However the Life-table plots illustrate the aggregate feature of the data but they suffer from the fact that the four sub-samples may not be comparable. Even if the survivor function for graduates in Humanities, for example, lies above that of graduates in Engineering, Engineering may be having a beneficial effect because its graduates have more valued attributes than their fellows. For this reason, I have also estimated proportional hazard models in the following section.

\subsection{Results from the Single Risk Models}

In this section, I will discuss and report the estimation results from the complementary log-log model (see equation 3). Both homogeneous and mixing proportional hazards have been estimated. The mixing models estimated assumes that the distribution of the unobserved heterogeneity is either gamma or discrete. All the estimated results are reported in table 7 .

In the specification without unobserved heterogeneity the estimated coefficients of the duration dependence ${ }^{17}$ reveal that the baseline hazard decreases to a single

\footnotetext{
${ }^{15}$ The estimates are available on request.

${ }^{16}$ Log-rank and Wilcoxon tests have respectively a chi2 equal to 331 and 302 .

${ }^{17}$ The baseline hazard functions are calculated by setting all covariate values equal to zero.
} 
minimum and then increases toward infinite thereafter. The baseline hazard function estimated under the assumption of either gamma or discrete distribution is fairly similar to the one without unobserved heterogeneity, though there are some differences in the magnitude of the estimated hazards ${ }^{18}$. Hence the results obtained indicate that there is a general evidence of true positive duration dependence after a short initial period of negative duration dependence. The initial negative duration dependence could be consistent with the following explanations. On one hand, university graduates could be very selective with respect to job opportunities because they have very high labour market expectations. On the other hand, they could be temporarily out of the labour force in the first quarters immediately after graduation as the extra utility obtained from being unemployed (leisure) is high and positive, i.e. the disutility arising from the social stigma attached to being unemployed and the debilitating effects of being unemployed are very low. The subsequent true positive duration dependence could be explained by the fact that, as time proceeds, they become less selective because they (feeling either discouraged or desperate) adjust their search effort and methods over the course of a given spell: an individual may look initially only into the best jobs available for a person with his or her skills, but look into less desirable opportunities later in a spell. Another possible explanation for true positive duration could be that during the unemployment spell, university graduates get more and more informed on where and which job opportunities are available and this increased search ability influences positively the hazard of getting the first job.

The effects of covariates on the hazard of exit from unemployment are very similar across the three models estimated, even though the estimated coefficients of the mixing proportional hazard models are generally greater in absolute terms than the ones of the homogeneous proportional hazard model. Comparing the maximum of the loglikelihoods from the models shows that the one with discrete unobserved heterogeneity has an edge over the other two models. As a result, I will discuss the covariate effects on the hazard relying on the discrete unobserved heterogeneity.

Starting with the effect of personal characteristics on the hazard of exit out of unemployment, older graduates are found to have a lower hazard of employment compared with their younger counterparts: a one year rise in age is associated with a $6 \%$ lower hazard rate. This could be explained by the fact that younger students are more likely to be better students or signal themselves as more able individuals to firms because they might have received their degree in the institutional time established for the course programme they attended. This is not however supported by the negative sign of the dummy variable equal to one if the individual has taken her degree in the institutional time: better students could also be choosier with respect to job opportunities than their counterparts taking longer to get their degree. With regard to gender differences, female graduates have a $20 \%$ lower hazard of employment compared with male graduates. An explanation for this that best fits the labor economics literature is, of course, that men are generally expected to receive more job offers than women are, mainly

\footnotetext{
${ }^{18}$ This supports Meyer's (1990) suggestion that using a flexible specification for the baseline hazard removes the sensitivity of estimated parameters to the type of distribution assumed for unobserved heterogeneity.
} 
due to the female labor market behavior that is (or perceived to be) characterized by frequent interruptions.

Graduates who transferred into another region to attend university have not a statistically different hazard of finding their first job. This could indicate that individuals who moved to another region to study may be not necessarily more motivated and better students than those who didn't experience any transfer. This does not support the idea that in a labour market highly segmented at the regional level, like the Italian one, not only where people work, but also where people study matters for their occupational outcomes ${ }^{19}$. Graduates who were employed in the labour market while studying have a $15 \%$ lower hazard of exit from unemployment: this is not in line with the a-priori that employers prefer individuals with some work experience, though seasonal or occasional; probably this result could be explained by the fact that these work experiences seem not to provide those skills that are useful to obtain a job.

Considering the covariate related to academic ability, the university final mark has not a statistically significant effect on the probability of obtaining the first job. The low influence of the final mark might be explained by the previously mentioned ceiling effect. The score and type of high school seem not to exert any impact on the hazard of employment too. However there are significant differences in graduates' hazard of employment according to subject studied at university, even using the highly aggregated set of 4 broad subject areas. Relative to students of Scientific subjects, Engineering students have a $28 \%$ higher hazard rate of getting the first job. The equivalent hazards for Social sciences and Humanities students are respectively $14 \%$ and $32 \%$ lower $^{20}$. These results may stress that the links between universities and employers are closer for some degrees (Engineering and Scientific) than for others (Humanities). Universities and employers are in an interdependent relationship in which employers depend on universities to supply educated workers and universities depend on employers to hire their graduates.

As regards the graduates' social background, educational level of the parents at the date of degree seems to have a positive effect on the probability of obtaining the first job. Thus for example, graduates with both parents with high school degree have a $10 \%$ higher hazard of employment with respect to graduates with parents having the lowest level of education (illiteracy or primary school). Also the father's occupation seems to have a positive influence on the graduates' chances of employment: those with a father manager or entrepreneur have higher hazard rates with respect to those with a father employed in non-qualified occupations. As formulated by Rees and Gray (1982) and Pistaferri (1999), youth unemployment may depend on contacts or the influence parents bear on the labour market (informal search channels). In this case, the greater the parents' influence, the lower the probability of being unemployed. In my

\footnotetext{
${ }^{19}$ See also Makovec (2005) who shows the existence of a positive and significant wage premium associated to attending university in the North rather than in the South.

${ }^{20}$ The lack of exclusion restrictions does not allow me to model simultaneously the hazard equation and an instrumented equation to control for endogeneity of the choice of college major. The estimated correlations could give some useful guidance on the true causal effects given that I control for a large set of covariates and for unobserved heterogeneity besides college major; this should at least attenuate omitted variable bias.
} 
analysis, the father's occupation is viewed as a proxy for influence. Hence, according to the estimation results, at the beginning of their professional career young people from lower socio-economic groups are faced with more restricted access to networks for job recruitment compared with their counterparts from a higher socio-economic group. Moreover the common wisdom in the economics literature is that jobs created through informal contacts are of better quality and pay higher wages than jobs created through formal methods. However Pellizzari (2004) documents that informal search channels not always lead to significantly better paid jobs. Across countries and industries wage premiums and wage penalties to find jobs through personal contacts are equally frequent. Pellizzari argues that such variation can be explained by looking at firms' recruitment strategies. In labour markets where employers invest largely in formal recruitment activities, matches created through this channel are likely to be of average better quality than those created through informal networks.

Finally the estimated results suggest strong regional variation in the patterns of exit from unemployment. Those individuals who attended university in Southern and Central Italy have longer duration of unemployment compared with their counterparts in the North of the country. In particular, those who took their degree in the Centre and South of the country have a $32 \%$ and $48 \%$ lower hazard rate of employment compared with their counterparts in the North of Italy. Since there is a strong correlation between region of university attended and region of actual residence (Brunello and Cappellari 2007 document that the percentage of individuals who currently work in the same area where they went to college is close to three quarters of the population of graduates), the geographical variables used here serve as proxy for local labour market conditions that are usually captured using local unemployment and vacancy rates.

\subsection{Results from the Independent Competing Risk Model}

I now consider the issue of destination state. Sample means of jobless duration and of number of exits are given in Table 8. Comparing individuals entering in to fixed-term contracts with individuals entering in to open-ended employment, it can be seen that their elapsed unemployment duration is much longer. However, the most common form of transition is to open-ended contracts rather than fixed-term employment.

The disaggregated version of the piecewise constant hazard regressions (under the assumption that exits can occur at interval boundaries) are given in Table 5. The estimates correct for unobserved heterogeneity , assuming a gamma mixing distribu$\operatorname{tion}^{21}$. It is immediately apparent that the regression coefficients vary from destination state to destination state. Thus, for example, the probability of finding employment in open-ended contracts is slightly increasing with the level of education of parents. But these effects of parental education are confined to open-ended contracts. This is also true if we consider the father's occupation: having a father either entrepreneur

\footnotetext{
${ }^{21}$ It is important to stress that in these models unobserved heterogeneity is not an issue in the fixed-term hazard regression: the likelihood ratio test of zero unobserved heterogeneity for the gamma distribution is accepted.
} 
or manager or professional worker or white collar high level increases the hazard rate of open-ended employment but not of fixed term contract. Female graduates have an higher hazard of exit to fixed term contracts but a lower hazard of exit to open-ended employment compared to their male counterparts. These findings warn against uncritical aggregation by destination state. Another interesting result is that graduation in Social Sciences is associated with a reduced likelihood of entering into fixed-term contracts. This is not true if we consider the probability of open-ended employment. On the other hand, graduation in Humanities seems to reduce the probability of escaping in to both permanent and fixed term jobs. Mobility increases the probability of fixed term employment but it has no direct effect on permanent employment. Those who took their degree in the Centre of Italy are less likely to enter open-ended employment than their Northern Italian counterparts. This is not true if we consider fixed term contract state. On the other hand southern graduates are less likely to exit to both states, though this effect is more pronounced if we consider exit to open-unemployment contract. As in the previous models, age and work experience while at university have a negative effect on the hazard of exit from unemployment. The final mark at university and high school score and type are not statistically significant. Very similar results are obtained estimating a multinomial logit model, under the assumptions that the interval-hazard is small and that the continuous hazard is constant within intervals.

Baseline hazard functions, corresponding to the piecewise constant exponential specification, are given in figure $6^{22}$. It is apparent that the baseline hazards are both characterized by declining escape rates over the first quarters, later there is evidence of positive duration dependence. Indeed, open-ended employment is generally characterized by higher hazard rates with respect to those of fixed-contracts state ${ }^{23}$. However in the final quarters there is a sharp increase of hazard of exit to fixed-term contracts. Taken in conjunction the two baseline hazards perhaps suggest that some graduates initially looking for open-ended employment switch to sampling fixed-term contracts after a period of unsuccessful search.

\subsection{Sensitivity Analysis}

This section reports the robustness of the previous results referred to as the "main analysis" or the "main results".

Firstly, I investigate whether there is some heterogeneity in the results between women and men and between individuals living in the North and individuals living in the Centre and South of Italy. Secondly, I will extend the analysis using the $2004^{24}$ wave of the graduates' employment survey to assess if the main results especially for the baseline hazard functions, i.e. true duration dependence, are not simply related to

\footnotetext{
${ }^{22}$ These results are obtained by setting all covariate values equal to zero.

${ }^{23}$ It is important to note that the coefficients of the fixed term destination state are very imprecisely estimated.

${ }^{24}$ I'm not able to extent the analysis using the 1998 survey because it does not provide information of the precise date of graduation and it prevents me to precisely calculate the spell of unemployment till the first job.
} 
macroeconomic trends or business cycles. All the estimation results of the sensitivity analysis are reported in Appendix B.

\subsubsection{Separate Analysis by Gender and Macro-regions}

In order to examine whether there is some heterogeneity in the pattern of duration dependence and in the covariates effects between women and men, the sample is divided by sex, and the equation (3) is estimated separately for each sub-sample. In brief, a part from few exceptions, there is not considerable heterogeneity between the sexes, which is discovered by comparing the regression coefficients (see tables $1 \mathrm{~B}$ and $2 \mathrm{~B}$ in Appendix B). The baseline hazard functions for both males and females are characterized by positive duration dependence after a short period of negative duration dependence as in the main analysis (see figures $1 \mathrm{~B}$ and $2 \mathrm{~B}$ in appendix $\mathrm{B}$ ). With regard to the covariates effects, we can see that female graduates who have taken their degree in the institutional time established for the course programme they attended seem to be less likely to find the first job. This is not the case for male graduates: the covariate institutional time has a positive coefficient, though very imprecisely estimated. On the other hand university final mark seems to influence negatively the hazard of employment for males but not for females. These results are in contrast with what has been found in the previous literature in this field: Biggeri et al (2001), for example, find that academic ability is more important for female graduates than for male ones. Lastly there seems to be some heterogeneity in the effects of family background: father's occupation seems to be more important for females than males. This result could be motivated with the fact that males have an advantage in finding a job over females and they don't depend on contacts or influence parents bear on the labour market.

I also run separated regressions by macro-regions (North versus Centre-South). The pattern of duration dependence for graduates studying both in the North and in the Centre-South of Italy is very similar to the one estimated in the main analysis (see figures 3B and 4B in Appendix B). The regression coefficients are fairly similar across the two sub-samples with the only exceptions of university groups and family background (see tables 3B and 4B in Appendix B). With regard to the formers, we can see that on one hand engineering is more effective in the North than in the CentreSouth. On the other it is interesting to note that graduates in social sciences and humanities are less penalized in terms of the hazard of first job in the North than in the Centre-South of Italy. These results confirm that local labour market conditions differ greatly from region to region. Concerning the father's occupation, this seems to be more important in the North rather than in the Centre-South. This could be motivated by the fact that graduates in the North search their first job mainly in the private sector where the informal channels may count more than in the public one.

\subsubsection{Results Using 2004 Wave of the Graduates' Employment Survey}

In this section, the analysis of the determinants of the time to obtain the first job is accomplished by using the most recent survey on job opportunities for the Italian 
high school graduates. The sample consists of nearly 26,000 records and it has been reduced to 16,000 by eliminating those who: i) don't participate to the labor market after graduation; and ii) were employed and took their job while at university. The definitions of covariates used in the analysis are reported in the appendix A along with their sample means.

With regard to the results of the single risk model, there is again evidence of true positive duration dependence after a short period of negative duration dependence (see figure 5B in Appendix B). The pattern of duration dependence estimated under the assumption of gamma or discrete distribution is similar to the one without unobserved heterogeneity, though as in the main analysis there are some differences in the magnitude of the estimated hazards from the three models. Once again it seems that, with the only exception of the first quarters, the more the university leavers stay unemployed the more likely they are to become employed in the future. The covariates effects on the hazard are fairly similar to the ones estimated with the 2001 sample: female graduates, those who graduated in Humanities, those who have parents with the lowest level of education and with a father employed in non qualified jobs and finally those who attended university in Southern and Central Italy are found to have particularly lower hazard of getting their first job. Contrary to the main results, however, we can see from table 13 that the academic ability, proxied by university final marks, seem to influence negatively the chances of getting the first job. This could be interpreted with the result that the most brilliant students are getting choosier with respect to job opportunities. This interpretation is not however supported by the coefficients of other proxies of individual ability: those students who take their degree in the institutional time and those who take a general high school degree seem to be more likely, rather than less likely, to get the first job.

\section{Conclusions}

This paper analyses the duration of unemployment for Italian graduates. The focus of the study has been on the time to obtain the first job, taking into account the graduates' characteristics and the effects relating to field of study. Semi-parametric discrete-time models have been used to study the hazard of exit to first job. Alternative mixing distributions have also been employed to account for unobserved heterogeneity. The estimated coefficients of the duration dependence reveal that the baseline hazard decreases to a single minimum and then increases toward infinite thereafter: a period of negative duration dependence is followed by positive duration dependence. The true positive duration dependence could be explained by the fact that university graduates tend to be choosier with respect to job opportunities in the first quarters after graduation. As time proceeds, they become less selective because they (feeling either discouraged or desperate) adjust their search effort and methods over the course of a given spell: an individual may look initially only into the best jobs available for a person with his or her skills, but look into less desirable opportunities later in a spell. Very similar results are obtained using the 2004 wave of the graduates' employment 
survey.

With regards to the effects of covariates, older and female graduates, those who graduated in Humanities and Social Sciences, those who had fathers employed in nonqualified occupations and finally those who attended university in Southern and Central Italy are found to have particularly lower hazard of getting their first job. Sensitivity analysis indicate that there is some heterogeneity in the results by gender and by macro-regions.

In addition, competing risk model has been estimated to characterize transitions out of unemployment, accommodating behaviorally distinct choices on the part of job seekers. My results reveal that the use of an aggregate approach sometimes compound distinct and contradictory effects. Thus, for example, the probability of finding employment in open-ended contracts is increasing with the level of education of parents. This is also true if we consider father's occupation: having a father either entrepreneur or manager or professional worker or white collar high level increases the hazard rate of open-ended employment but not of fixed term contract. But these effects are completely absent if we consider exit to fixed-term contracts. Female graduates have a higher hazard of exit to fixed contracts but a lower hazard of exit to open-ended employment compared to their male counterparts. Those who took their degree in the Centre of Italy are less likely to enter open-ended employment than their Northern Italian counterparts, this is not true if we consider exit to fixed term contract.

A lot of research remains to be done, and there are many open questions. What are the effects of the recent reforms of university system on the hazard rate of employment of Italian graduates? Does it ease the transition from university to work? Which is the tenure of the first job and how many transitions do the Italian university graduates experiment before finding a stable and long-lasting occupation? Future research will have to address these questions. 


\section{References}

[1] Abbring J.H. and Van den Berg G. J. (2007), "The Unobserved Heterogeneity Distribution in Unobserved Heterogeneity " Biometrika, 94, 1: 87-99.

[2] Arulampalam W., Booth A.L., Taylor M.P. (2000), "Unemployment Persistence " Oxford Economic Papers, 52: 24-50.

[3] Biggeri L., Bini M. and Grilli L. (2000), "The transition from university to work: a multilevel approach to the analysis of the time to obtain the first job", J. R. Statistical Society A, 164: 293-305.

[4] Brunello G. and Cappellari L. (2007), "The labour market effects of Alma Mater: Evidence from Italy", forthcoming in: Economics of Education Review.

[5] Censis, "Rapporto sulla situazione del Paese, anno 1999".

[6] Checchi D. (2001), "Primi risultati dell'indagine sui percorsi lavorativi dei laureati dell'ateneo di Milano: Facoltà di Scienze Politiche", mimeo, University of Milan.

[7] Ghirardini P. G. and Pellinghelli M. (2000), "I non disoccupati Laureati e diplomati nell'Italia della piena occupazione", Mulino.

[8] Heckman J. and B. Singer (1984a) "The identifiability of The Proportional Hazard Model", Review of Economic Studies, LI: 231-241.

[9] Heckman J. and B. Singer (1984b) "A Method for Minimizing the Impact of Distributional Assumptions in Econometric Models for Duration Data", Econometrica, 52(2): 271-320.

[10] ISTAT, "Rilevazione delle forze di lavoro, anno 1999".

[11] ISTAT, "Rapporto annuale, 1998".

[12] Jenkins S. P. (1995), "Easy Estimation Methods for Discrete-Time Duration Models" Oxford Bulletin of Economics and Statistics, 57(1): 129-138.

[13] Jenkins, S. P. (1997), "sbe17: Estimation Methods for Discrete-Time (Grouped Duration Data) Proportional Hazard Models: PGMHAZ", Stata Technical Bulletin, 39: 1-12.

[14] Lancaster T. (1979), "Econometric Methods of the Duration of Unemployment" Econometrica, 47(4): 939-956.

[15] Lynch L. M. (1985), "State Dependency in Youth Unemployment: A Lost Generation?" Journal of Econometrics, April 1985: 71-84.

[16] Margolis D. N., Plug E., Simonnet V. and Vilhuber L. (1999), "The role of early career experiences in determining later career success: An international comparison" unpublished paper, TEAM-Universite de Paris 1 Pantheon-Sorbonne. 
[17] Makovec M. (2005), “Does it pay studying far from home? Explaining the returns to geographic mobility of Italian graduates" IGIER discussion paper.

[18] Meyer B. D. (1990), "Unemployment Insurance and Unemployment Spells" Econometrica 58: 757-782.

[19] Mroz T. A. and Savage T. H. (1999), "The long-term effects of youth unemployment, Department of Economics" University of North Carolina.

[20] Narendranathan W. and Elias P. (1993) "Influences of Past History on the Incidence of Youth Unemployment: Empirical Findings for the UK", Oxford Bulletin of Economics and Statistics, 55: 161-85.

[21] Nickell S. (1979) "Estimating the probability of leaving unemployment ", Econometrica 47: 1249-1266.

[22] OCSE, "Regard sur l'education ", 1997.

[23] Omori Y. (1997), "Stigma Effects of Nonemployment" Economic Inquiry, vol. 35: $394-416$

[24] Pellizzari M. (2004), "Do Friends and Relatives Really Help in Getting a Good Job?" CEP discussion paper No 623.

[25] Pistaferri L. (1999), "Informal Networks in the Italian Labor Market" Giornale degli Economisti e Annali di Economia, 58(3-4): 355-375.

[26] Rees A. and Gray W. (1982), "Family effects in youth employment" in R. B. Freeman, The youth labor market problem: Its nature, causes and consequences. Chicago: University of Chicago Press.

[27] Santoro M. and Pisati M. (1996), "Dopo la laurea" Bologna: Il Mulino.

[28] Staffolani S. and Sterlacchini A., (2001), "Istruzione universitaria, occupazione, e reddito. Un analisi empirica sui laureati degli atenei marchigiani", F.Angeli.

[29] Tronti L. and Mariani P. (1994), "La transizione Università-Lavoro in Italia: un'esplorazione delle evidenze dell'indagine ISTAT sugli sbocchi professionali dei laureati", Econ. Lav., 25, no. 3: 3-26.

[30] Van den Berg G. (2001), "Duration Models: Specification, Identification and Multiple Durations", in Handbook of Econometrics, edited by Heckman, James J. and Leamer Edward, V, North-Holland, Amsterdam.

[31] Vitale C. (1999), "Indagine sugli sbocchi dei laureati dell'università di Salerno", mimeo, Università di Salerno. 


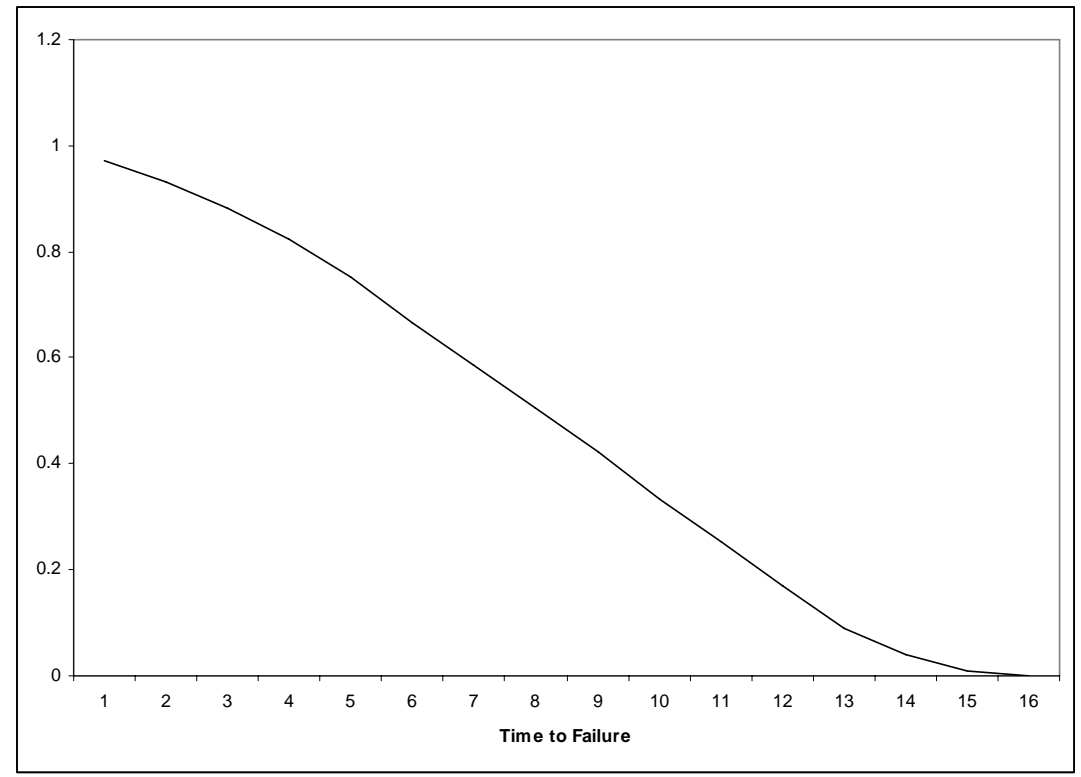

Figure 1: Empirical Survivor Function.

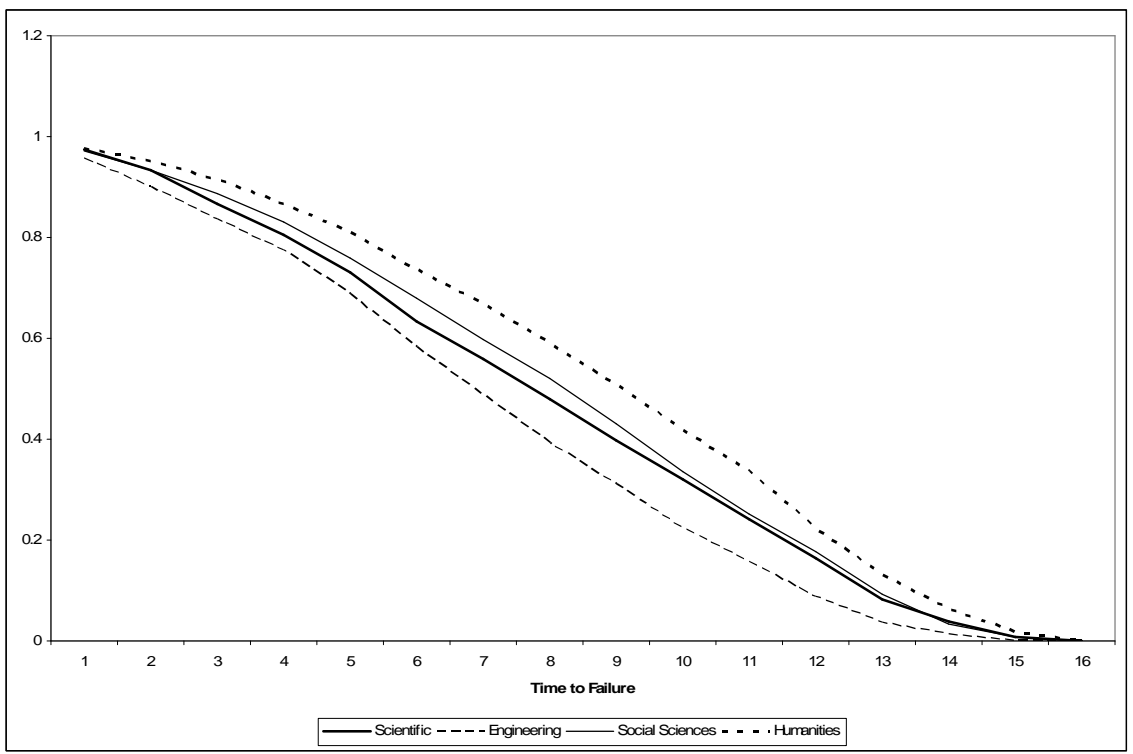

Figure 2: Empirical Survivor Function by University Group. 




Figure 3: Empirical Hazard Function.

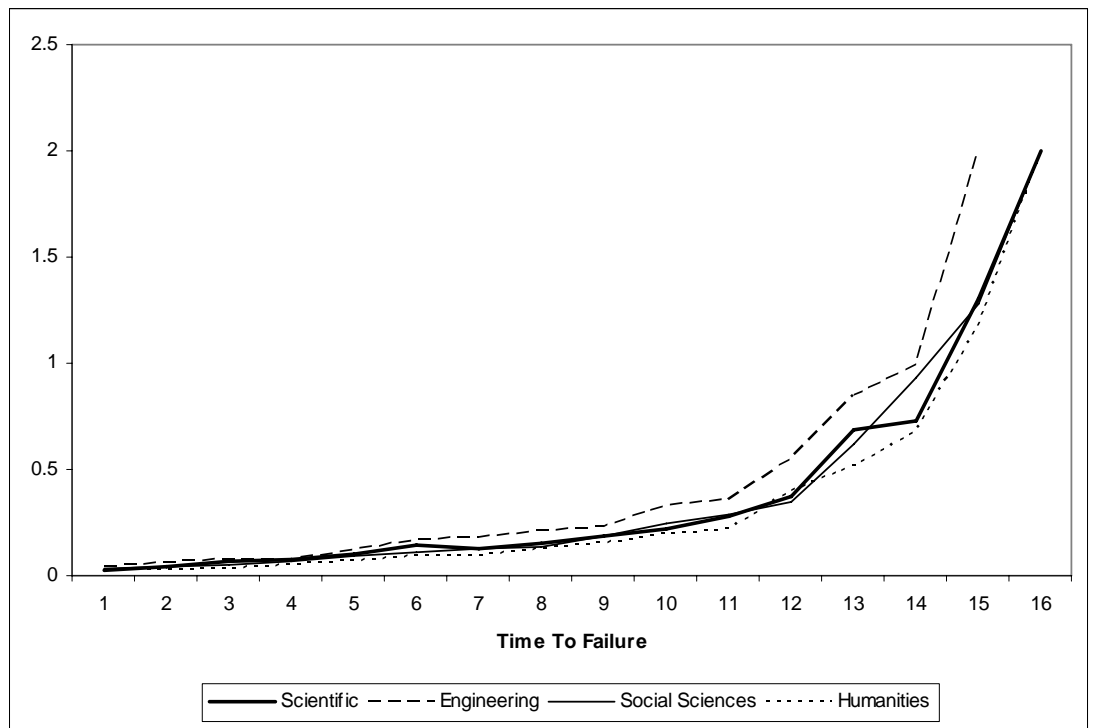

Figure 4: Empirical Hazard Function by University Group. 


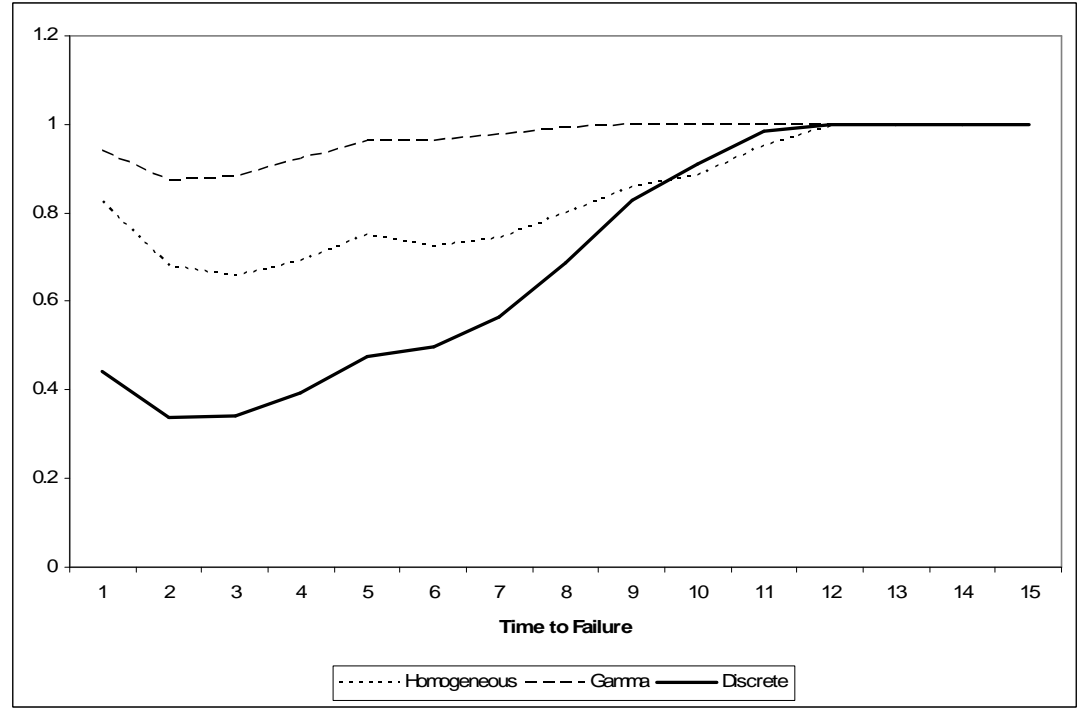

Figure 5: Baseline Hazard Function (Sample 2001).

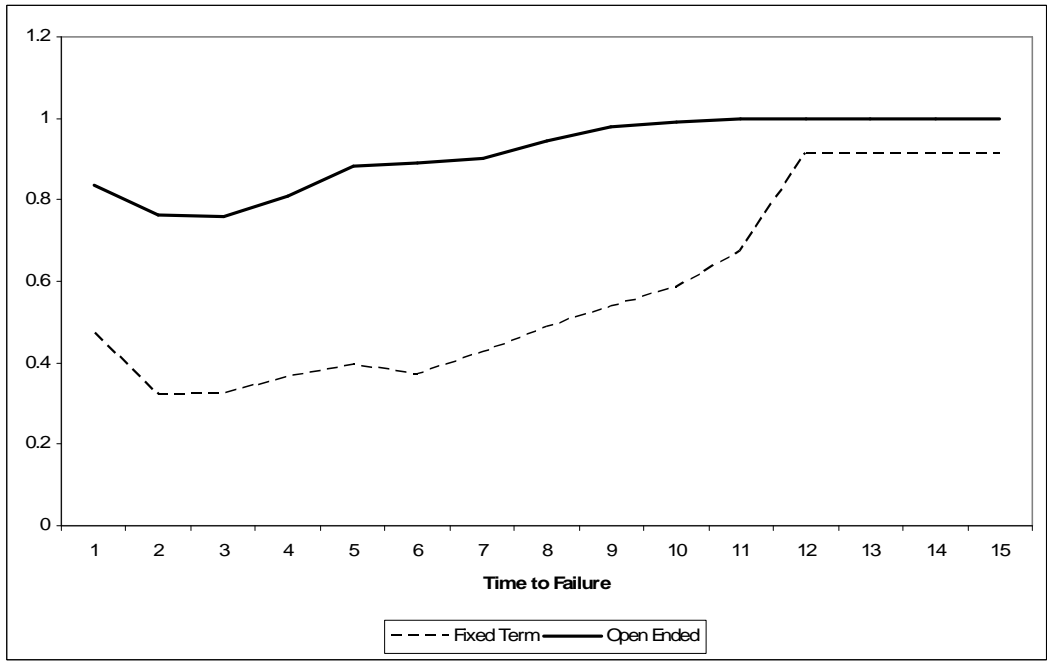

Figure 6: Baseline Hazard Function by Destination State (Sample 2001). 
Table 1: Distribution of university groups.

\begin{tabular}{lcc}
\hline University groups & $\mathbf{N}$ & $\mathbf{\%}$ \\
& & \\
\hline Scientific & 3,684 & 22.75 \\
Engineering & 3,118 & 19.25 \\
Social sciences & 5,501 & 33.97 \\
Humanities & 3,892 & 24.03 \\
& & \\
Total & 16,195 & 100 \\
\hline \hline
\end{tabular}

Table 2: Length of graduates' unemployment.

\begin{tabular}{lccc}
\hline & Total & Females & Males \\
\hline \hline from 0 to 3 quarters & 34.13 & 32.07 & 36.45 \\
from 4 to 7 quarters & 24.5 & 22.51 & 27.03 \\
from 7 to 11 quarters & 14.54 & 14.01 & 15.08 \\
quarters $\geq 11$ & 26.83 & 31.41 & 21.44 \\
\hline \hline
\end{tabular}


Table 3: Distribution of unemployment spells by parental education.

\begin{tabular}{lccccccc}
\hline Unemployment spells & \multicolumn{7}{c}{ Parental Education } \\
& level 1 & level 2 & level 3 & level 4 & level 5 & level 6 & level 7 \\
\hline from 0 to 3 quarters & 12.47 & 9.78 & 15.06 & 17.89 & 19.35 & 15.03 & 10.41 \\
from 4 to 7 quarters & 12.59 & 9.88 & 14.92 & 18.01 & 19.38 & 15.63 & 9.6 \\
from 7 to 11 quarters & 13.5 & 8.63 & 14.15 & 18.72 & 18.03 & 17.61 & 9.36 \\
quarters $\geq 11$ & 14.48 & 9.16 & 13.51 & 17.6 & 19.01 & 16.78 & 9.46 \\
Total & 13.19 & 9.47 & 14.48 & 17.96 & 19.08 & 16.02 & 9.81 \\
\hline \hline
\end{tabular}

Notes: level 1: both parents elementary school; level 2: at least one parent junior high school; level 3: both parents junior high school; level 4: at least one parent high school; level 5: both parents high school; level 6: at least one parent university; level 6: both parents university.

Table 4: Distribution of unemployment spells by university groups.

\begin{tabular}{lcccc}
\hline Unemployment spells & \multicolumn{4}{c}{ University groups } \\
& scientific & engineering & social sciences & humanities \\
\hline from 0 to 3 quarters & 23.94 & 25.13 & 32.48 & 18.45 \\
from 4 to 7 quarters & 23.87 & 20.82 & 33.82 & 21.5 \\
from 7 to 11 quarters & 21.32 & 17.79 & 35.12 & 25.77 \\
quarters $\geq 11$ & 20.99 & 11.14 & 35.37 & 32.5 \\
\hline \hline
\end{tabular}

Table 5: Distribution by destination state and mean durations (2001).

\begin{tabular}{lcccc}
\hline \multicolumn{5}{c}{ first job } \\
\hline status & noexit & exit & Total & mean duration \\
\hline unemployed & 100 & 0 & 19.51 & $16(0)$ \\
fixed-term & 0 & 37.84 & 30.45 & $4.84(3.95)$ \\
open-ended & 0 & 62.16 & 50.03 & $4.23(3.64)$ \\
\hline & 19.51 & 80.49 & 100 & \\
\hline
\end{tabular}


Table 6: Results of the single risk model (Sample 2001).

\begin{tabular}{|c|c|c|c|c|c|c|}
\hline \multirow[b]{2}{*}{ Variables } & \multicolumn{2}{|c|}{ Homogeneus } & \multicolumn{2}{|c|}{ Gamma Mixing } & \multicolumn{2}{|c|}{ Discrete Mixing } \\
\hline & Coefficient & $\mathrm{P}$-value & Coefficient & P-value & Coefficient & $\mathrm{P}$-value \\
\hline \multicolumn{7}{|l|}{ Duration dependence: } \\
\hline quarter 1 & 0.556 & 0.103 & 1.039 & 0.025 & -0.544 & 0.247 \\
\hline quarter 2 & 0.130 & 0.704 & 0.727 & 0.119 & -0.890 & 0.059 \\
\hline quarter 3 & 0.067 & 0.844 & 0.750 & 0.110 & -0.878 & 0.064 \\
\hline quarter 4 & 0.166 & 0.628 & 0.929 & 0.049 & -0.698 & 0.142 \\
\hline quarter 5 & 0.323 & 0.344 & 1.175 & 0.013 & -0.436 & 0.360 \\
\hline quarter 6 & 0.257 & 0.452 & 1.198 & 0.012 & -0.377 & 0.431 \\
\hline quarter 7 & 0.308 & 0.369 & 1.336 & 0.006 & -0.186 & 0.699 \\
\hline quarter 8 & 0.472 & 0.170 & 1.594 & 0.001 & 0.150 & 0.756 \\
\hline quarter 9 & 0.672 & 0.051 & 1.905 & 0.000 & 0.563 & 0.243 \\
\hline quarter 10 & 0.763 & 0.027 & 2.121 & 0.000 & 0.871 & 0.069 \\
\hline quarter 11 & 1.094 & 0.002 & 2.603 & 0.000 & 1.402 & 0.003 \\
\hline quarter 12 & 1.772 & 0.000 & 3.582 & 0.000 & 2.249 & 0.000 \\
\hline \multicolumn{7}{|l|}{ Personal characteristics: } \\
\hline gender & -0.152 & 0.000 & -0.227 & 0.000 & -0.222 & 0.000 \\
\hline graduation in due time & -0.123 & 0.005 & -0.151 & 0.009 & -0.174 & 0.002 \\
\hline mobility & 0.038 & 0.112 & 0.030 & 0.338 & 0.020 & 0.507 \\
\hline military service & -0.399 & 0.000 & -0.657 & 0.000 & -0.728 & 0.000 \\
\hline age & -0.052 & 0.000 & -0.065 & 0.000 & -0.065 & 0.000 \\
\hline workduruniversity & -0.100 & 0.000 & -0.157 & 0.000 & -0.148 & 0.000 \\
\hline \multicolumn{7}{|l|}{ Academic performance: } \\
\hline university final mark & -0.002 & 0.250 & -0.001 & 0.532 & -0.001 & 0.523 \\
\hline high school final mark & 0.002 & 0.281 & 0.003 & 0.159 & 0.002 & 0.400 \\
\hline general high school & 0.053 & 0.153 & 0.061 & 0.205 & 0.041 & 0.394 \\
\hline vocational/tech high school & 0.073 & 0.069 & 0.106 & 0.044 & 0.098 & 0.059 \\
\hline engineering & 0.183 & 0.000 & 0.220 & 0.000 & 0.247 & 0.000 \\
\hline social sciences & -0.094 & 0.002 & -0.150 & 0.000 & -0.149 & 0.000 \\
\hline humanities & -0.258 & 0.000 & -0.389 & 0.000 & -0.381 & 0.000 \\
\hline \multicolumn{7}{|l|}{ Parents' education: } \\
\hline parentaleducation2 & 0.071 & 0.104 & 0.128 & 0.029 & 0.115 & 0.044 \\
\hline parentaleducation3 & 0.076 & 0.056 & 0.104 & 0.050 & 0.102 & 0.055 \\
\hline parentaleducation 4 & 0.025 & 0.543 & 0.049 & 0.368 & 0.070 & 0.200 \\
\hline parentaleducation 5 & 0.056 & 0.201 & 0.065 & 0.256 & 0.097 & 0.090 \\
\hline parentaleducation6 & -0.046 & 0.340 & -0.070 & 0.267 & -0.042 & 0.509 \\
\hline parentaleducation7 & 0.057 & 0.298 & 0.108 & 0.135 & 0.134 & 0.062 \\
\hline \multicolumn{7}{|l|}{ Father's occupation: } \\
\hline entrepreneur & 0.071 & 0.175 & 0.153 & 0.029 & 0.132 & 0.051 \\
\hline professional worker & 0.029 & 0.568 & 0.078 & 0.246 & 0.045 & 0.496 \\
\hline own-account worker & 0.024 & 0.556 & 0.050 & 0.351 & 0.033 & 0.539 \\
\hline manager & 0.107 & 0.017 & 0.188 & 0.002 & 0.158 & 0.007 \\
\hline teacher/professor & -0.042 & 0.471 & -0.018 & 0.808 & -0.074 & 0.320 \\
\hline white collar high level & 0.064 & 0.132 & 0.101 & 0.069 & 0.070 & 0.203 \\
\hline white collar low level & 0.071 & 0.113 & 0.126 & 0.034 & 0.111 & 0.058 \\
\hline blue collar high level & 0.030 & 0.459 & 0.044 & 0.412 & 0.021 & 0.703 \\
\hline \multicolumn{7}{|l|}{ University Macro-regions: } \\
\hline North-East & -0.131 & 0.000 & -0.185 & 0.000 & -0.177 & 0.000 \\
\hline Centre & -0.257 & 0.000 & -0.385 & 0.000 & -0.373 & 0.000 \\
\hline South & -0.450 & 0.000 & -0.672 & 0.000 & -0.645 & 0.000 \\
\hline mass point 1 location & & & & & 0.000 & 0.000 \\
\hline mass point 1 probability & & & & & 0.236 & 0.000 \\
\hline mass point 2 location & & & & & 1.821 & 0.000 \\
\hline mass point 2 probability & & & & & 0.763 & 0.000 \\
\hline no of person-period obs & 45932 & & 45932 & & 45932 & \\
\hline Log-likelihood & -22662.713 & & -22632.176 & & -22586.316 & \\
\hline
\end{tabular}

Notes: Likelihood ratio statistic for testing zero gamma unobserved heterogeneity $=$ $61.072(\mathrm{P}$-value $=0)$. 
Table 7: Results of the independent competing risks model (Sample 2001).

\begin{tabular}{|c|c|c|c|c|}
\hline \multirow[b]{2}{*}{ Variables } & \multicolumn{2}{|c|}{ Fixed Term } & \multicolumn{2}{|c|}{ Open Ended } \\
\hline & Coefficient & $\mathrm{P}$-value & Coefficient & $\mathrm{P}$-value \\
\hline \multicolumn{5}{|l|}{ Duration dependence: } \\
\hline quarter 1 & -0.445 & 0.446 & 0.586 & 0.333 \\
\hline quarter 2 & -0.943 & 0.108 & 0.358 & 0.558 \\
\hline quarter 3 & -0.927 & 0.114 & 0.350 & 0.569 \\
\hline quarter 4 & -0.791 & 0.178 & 0.499 & 0.419 \\
\hline quarter 5 & -0.692 & 0.239 & 0.765 & 0.219 \\
\hline quarter 6 & -0.760 & 0.196 & 0.794 & 0.205 \\
\hline quarter 7 & -0.587 & 0.318 & 0.844 & 0.181 \\
\hline quarter 8 & -0.406 & 0.490 & 1.066 & 0.093 \\
\hline quarter 9 & -0.261 & 0.657 & 1.379 & 0.032 \\
\hline quarter 10 & -0.129 & 0.827 & 1.532 & 0.018 \\
\hline quarter 11 & 0.118 & 0.842 & 1.994 & 0.002 \\
\hline quarter 12 & 0.902 & 0.125 & 2.577 & 0.000 \\
\hline \multicolumn{5}{|l|}{ Personal characteristics: } \\
\hline gender & 0.124 & 0.003 & -0.404 & 0.000 \\
\hline graduation in due time & -0.216 & 0.002 & -0.043 & 0.548 \\
\hline mobility & 0.086 & 0.024 & 0.003 & 0.944 \\
\hline military sevice & -0.169 & 0.007 & -0.756 & 0.000 \\
\hline age & -0.076 & 0.000 & -0.035 & 0.023 \\
\hline workduruniversity & -0.107 & 0.003 & -0.128 & 0.000 \\
\hline \multicolumn{5}{|l|}{ Academic performance: } \\
\hline high school final mark & -0.004 & 0.166 & 0.007 & 0.014 \\
\hline general high school & 0.064 & 0.253 & 0.043 & 0.489 \\
\hline vocational/tech high school & 0.019 & 0.757 & 0.116 & 0.081 \\
\hline engineering & -0.079 & 0.162 & 0.351 & 0.000 \\
\hline social sciences & -0.259 & 0.000 & -0.013 & 0.785 \\
\hline humanities & -0.137 & 0.007 & -0.504 & 0.000 \\
\hline \multicolumn{5}{|l|}{ Parents' education: } \\
\hline parentaleducation2 & 0.018 & 0.802 & 0.163 & 0.026 \\
\hline parentaleducation3 & 0.017 & 0.793 & 0.143 & 0.031 \\
\hline parentaleducation 4 & -0.059 & 0.375 & 0.101 & 0.137 \\
\hline parentaleducation 5 & -0.028 & 0.686 & 0.105 & 0.143 \\
\hline parentaleducation6 & -0.102 & 0.188 & -0.022 & 0.785 \\
\hline parentaleducation7 & -0.035 & 0.692 & 0.161 & 0.075 \\
\hline \multicolumn{5}{|l|}{ Father's occupation: } \\
\hline entrepreneur & -0.075 & 0.388 & 0.261 & 0.003 \\
\hline professional worker & -0.138 & 0.105 & 0.196 & 0.019 \\
\hline own-account worker & 0.033 & 0.602 & 0.023 & 0.738 \\
\hline manager & 0.073 & 0.314 & 0.189 & 0.011 \\
\hline teacher/professor & -0.009 & 0.919 & -0.042 & 0.657 \\
\hline white collar high level & -0.017 & 0.799 & 0.157 & 0.023 \\
\hline white collar low level & -0.012 & 0.863 & 0.178 & 0.016 \\
\hline blue collar high level & 0.016 & 0.803 & 0.048 & 0.479 \\
\hline \multicolumn{5}{|l|}{ University Macro-regions: } \\
\hline North-East & -0.055 & 0.242 & -0.214 & 0.000 \\
\hline Centre & -0.068 & 0.155 & -0.491 & 0.000 \\
\hline South & -0.297 & 0.000 & -0.716 & 0.000 \\
\hline no of person-period obs & 45932 & & 29260 & \\
\hline Log-likelihood & -12217.018 & & -17193.746 & \\
\hline
\end{tabular}

Notes: Fixed Term Contract: Likelihood ratio statistic for testing zero gamma unobserved heterogeneity $=0.00001(\mathrm{P}$-value $=1)$; Open Ended Employment: Likelihood ratio statistic for testing zero gamma unobserved heterogeneity $=44.303(\mathrm{P}$-value $=$ $0)$. 


\section{Appendix A: Definitions of the Variables and Sample Averages.}

\begin{tabular}{lcc}
\hline Name and definition & Sample 2001 & Sample 2004 \\
\hline \hline Time (in quarters, from 0 to 16) & 4.377 & 2.922 \\
Mobility (1, transfer into another region; 0 otherwise) & 0.286 & 0.318 \\
Sex (0, male; 1, female) & 0.546 & 0.507 \\
Military service (0, done before degree or exempted; 1, otherwise) & 0.123 & - \\
Age & 28.374 & 27.961 \\
University final mark (integers from 66 to 110) & 102.862 & 103.762 \\
High school mark (integers from 36 to 60) & 48.821 & 49.139 \\
General high school & 0.618 & 0.610 \\
Vocational/technical high school & 0.272 & 0.326 \\
Other high school & 0.110 & 0.064 \\
Workduruniversity (1, at least one job during university , 0, otherwise) & 0.422 & 0.359 \\
Parentaleduc1 (both parents illiterate or with primary school certificate) & 0.132 & 0.110 \\
Parentaleduc2 (at least one parent with middle school certificate) & 0.095 & 0.099 \\
Parentaleduc3 (both parents with a middle school certificate) & 0.145 & 0.141 \\
Parentaleduc4 (at least one parent with a high school certificate) & 0.180 & 0.193 \\
Parentaleduc5 (both parents with high school certificate) & 0.191 & 0.194 \\
Parentaleduc6 (at least one parent with a degree) & 0.160 & 0.161 \\
Parentaleduc7 (both parents with a degree) & 0.098 & 0.103 \\
North-west (university in the north-west of Italy) & 0.275 & 0.277 \\
North-east (university in the north-east of Italy) & 0.228 & 0.120 \\
Centre (university in the centre of Italy) & 0.236 & 0.322 \\
South (university in the south of Italy) & 0.261 & 0.280 \\
Scientific (graduation in scientific subjects) & 0.227 & 0.228 \\
Engineering (graduation in engineering) & 0.193 & 0.263 \\
Social sciences (graduation in social, economic and political subjects) & 0.340 & 0.317 \\
Humanities (graduation in humanities) & 0.240 & 0.192 \\
entrepreneur & 0.055 & 0.054 \\
professional worker & 0.079 & 0.067 \\
own-account worker & 0.124 & 0.148 \\
manager & 0.156 & 0.096 \\
teacher/professor & 0.066 & 0.114 \\
white collar high level & 0.159 & 0.189 \\
white collar low level & 0.099 & 0.113 \\
blue collar high level & 0.129 & 0.189 \\
other occupation & 0.129 & 0.029 \\
\hline & & \\
& & \\
& &
\end{tabular}


Appendix B: Figures and Tables of the Sensitivity Analysis.

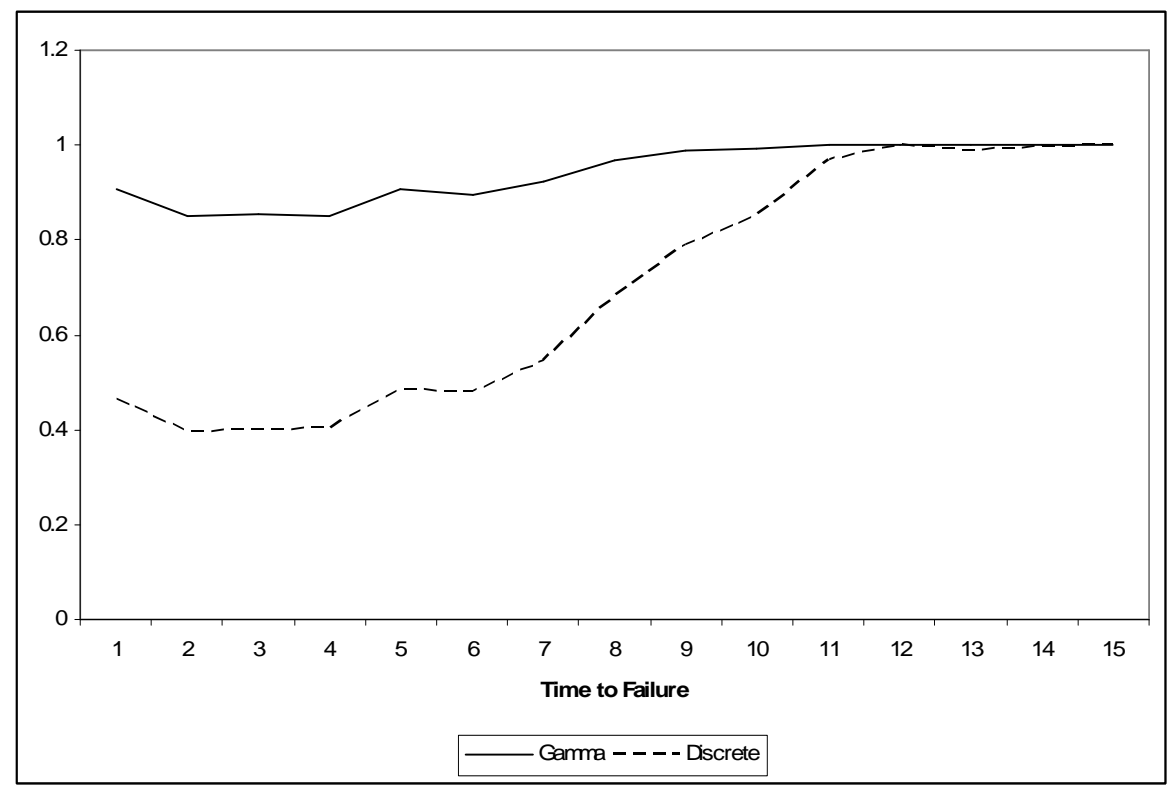

Figure 1B: Baseline hazard function for female graduates (Sample 2001). 


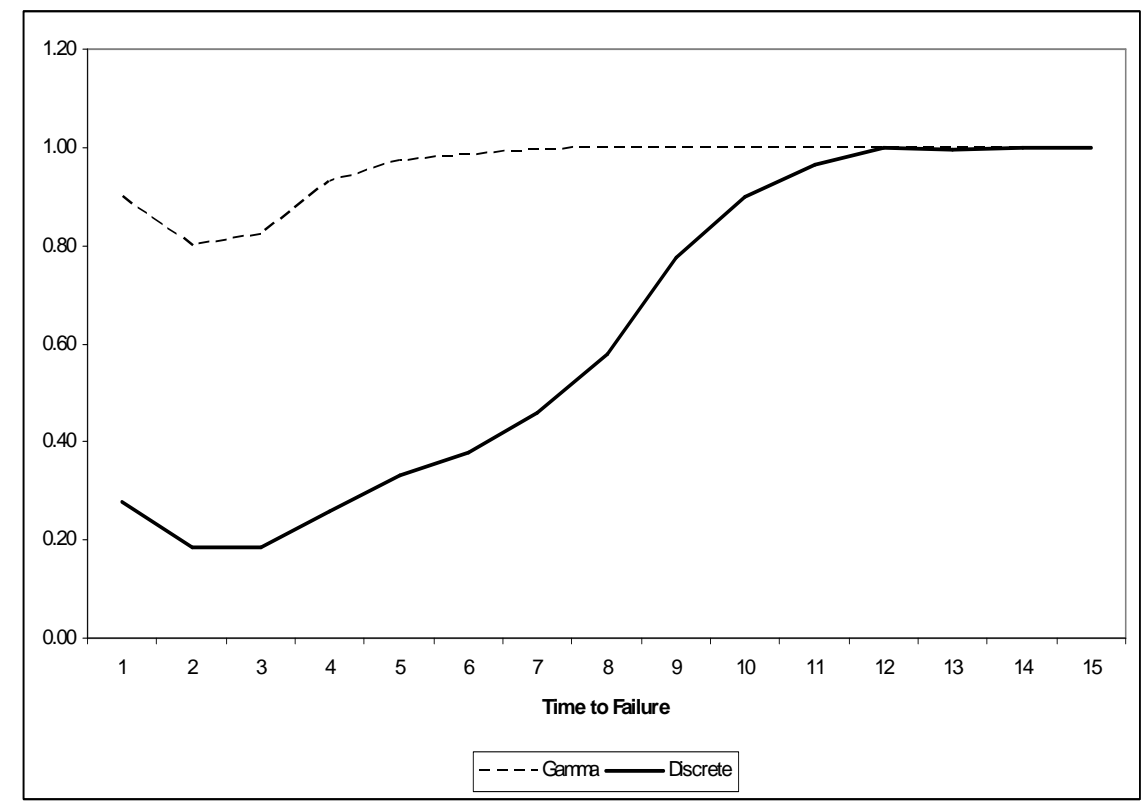

Figure 2B: Baseline hazard function for male graduates (Sample 2001). 


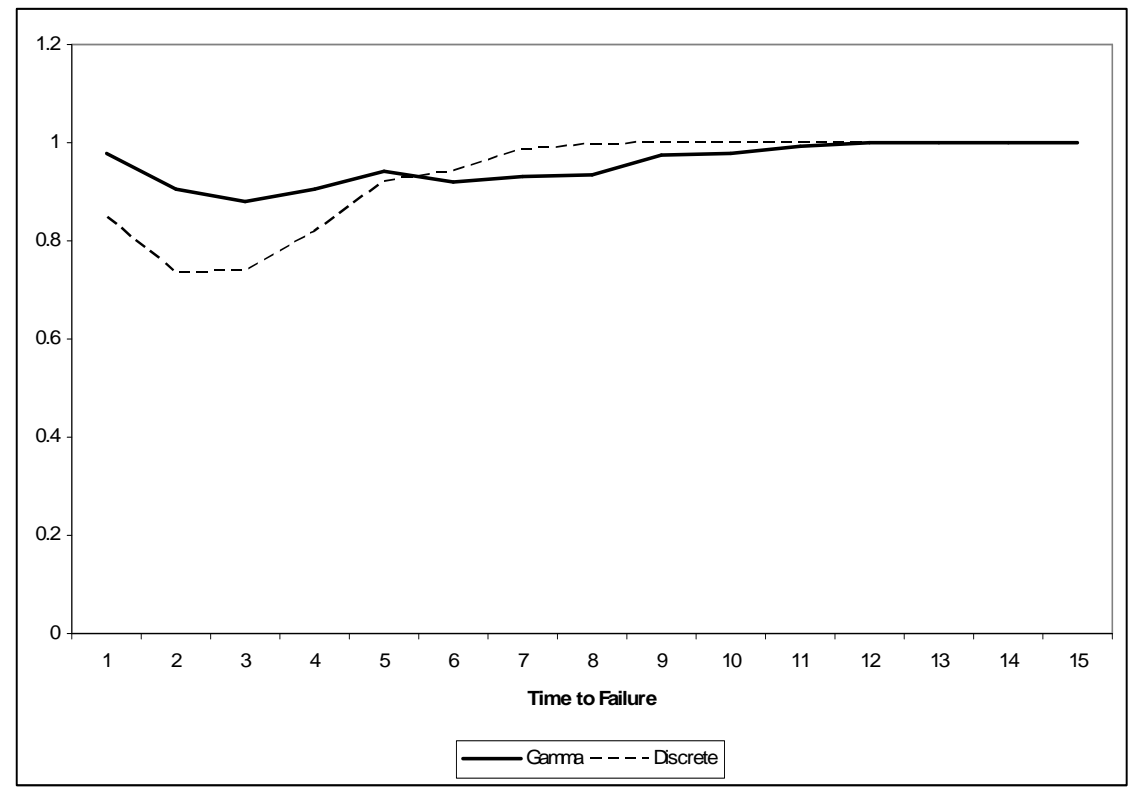

Figure 3B: Baseline hazard function for graduates in the North of Italy (Sample 2001). 


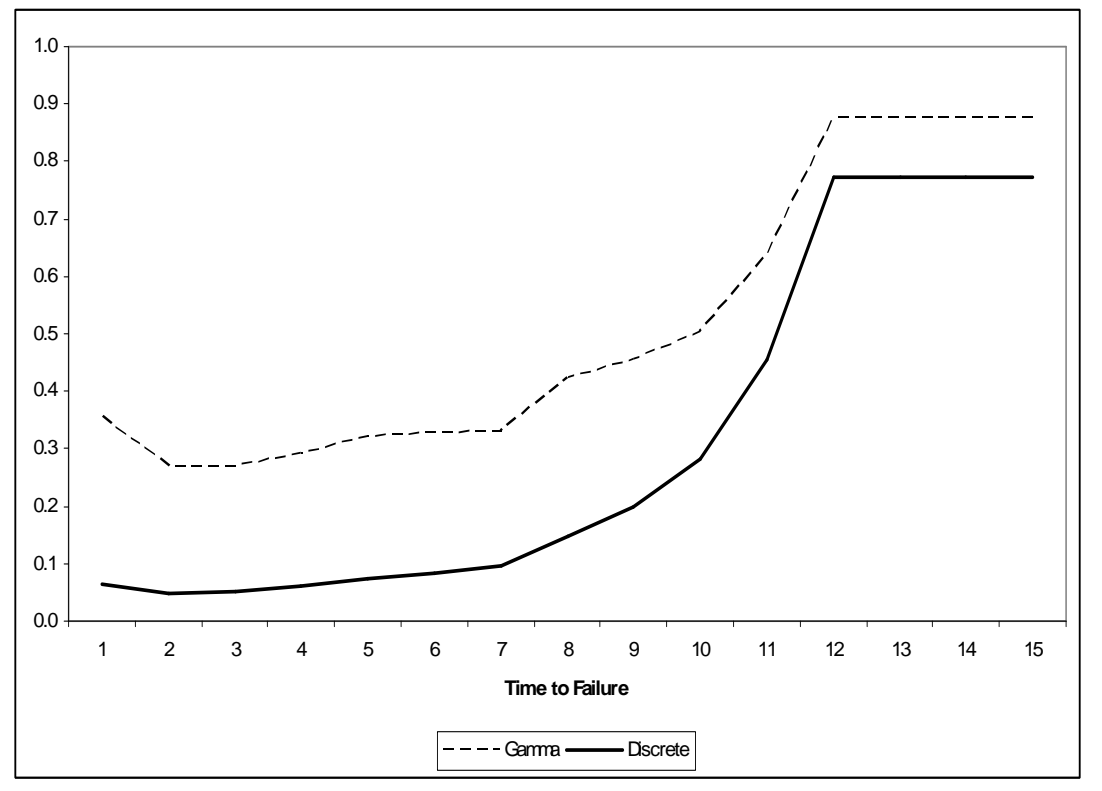

Figure 4B: Baseline hazard function for graduates in the Centre-South of Italy (Sample 2001). 


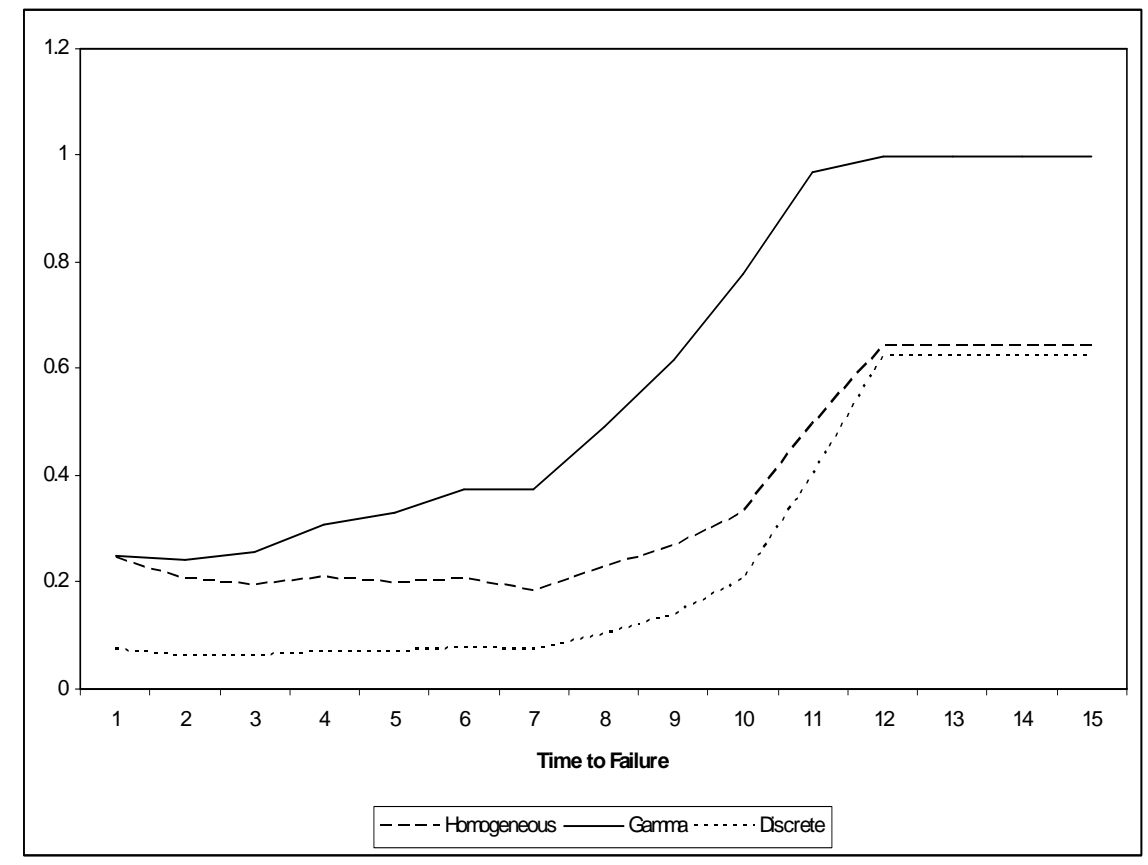

Figure 5B: Baseline hazard function (Sample 2004). 
Table 1B: Results of the single risk model (women, sample 2001).

\begin{tabular}{|c|c|c|c|c|c|c|}
\hline \multirow[b]{2}{*}{ Variables } & \multicolumn{2}{|c|}{ Homogeneus } & \multicolumn{2}{|c|}{ Gamma Mixing } & \multicolumn{2}{|c|}{ Discrete Mixing } \\
\hline & Coefficient & $\mathrm{P}$-value & Coefficient & $\mathrm{P}$-value & Coefficient & P-value \\
\hline \multicolumn{7}{|l|}{ "Duration dependence: } \\
\hline quarter 1 & 0.458 & 0.332 & 0.864 & 0.141 & -0.474 & 0.455 \\
\hline quarter 2 & 0.169 & 0.720 & 0.645 & 0.276 & -0.696 & 0.275 \\
\hline quarter 3 & 0.124 & 0.794 & 0.657 & 0.270 & -0.674 & 0.292 \\
\hline quarter 4 & 0.062 & 0.895 & 0.646 & 0.280 & -0.667 & 0.299 \\
\hline quarter 5 & 0.235 & 0.620 & 0.872 & 0.148 & -0.412 & 0.522 \\
\hline quarter 6 & 0.123 & 0.796 & 0.814 & 0.180 & -0.429 & 0.506 \\
\hline quarter 7 & 0.206 & 0.665 & 0.948 & 0.121 & -0.244 & 0.706 \\
\hline quarter 8 & 0.449 & 0.345 & 1.251 & 0.042 & 0.129 & 0.842 \\
\hline quarter 9 & 0.610 & 0.201 & 1.482 & 0.017 & 0.449 & 0.487 \\
\hline quarter 10 & 0.645 & 0.177 & 1.593 & 0.012 & 0.645 & 0.315 \\
\hline quarter 11 & 1.071 & 0.025 & 2.115 & 0.001 & 1.248 & 0.050 \\
\hline quarter 12 & 1.762 & 0.000 & 3.004 & 0.000 & 2.139 & 0.001 \\
\hline \multicolumn{7}{|l|}{ Personal characteristics: } \\
\hline graduation in due time & -0.199 & 0.000 & -0.224 & 0.001 & -0.261 & 0.000 \\
\hline mobility & 0.058 & 0.076 & 0.043 & 0.280 & 0.028 & 0.510 \\
\hline age & -0.067 & 0.000 & -0.081 & 0.000 & -0.087 & 0.000 \\
\hline workduruniversity & -0.129 & 0.000 & -0.181 & 0.000 & -0.177 & 0.000 \\
\hline \multicolumn{7}{|l|}{ Academic performance: } \\
\hline university final mark & 0.001 & 0.820 & 0.000 & 0.921 & 0.003 & 0.444 \\
\hline high school final mark & 0.003 & 0.212 & 0.005 & 0.088 & 0.003 & 0.283 \\
\hline general high school & 0.062 & 0.140 & 0.070 & 0.174 & 0.069 & 0.196 \\
\hline vocational/tech high school & 0.070 & 0.160 & 0.104 & 0.090 & 0.113 & 0.075 \\
\hline engineering & 0.203 & 0.000 & 0.264 & 0.000 & 0.333 & 0.000 \\
\hline social sciences & -0.058 & 0.163 & -0.076 & 0.134 & -0.085 & 0.109 \\
\hline humanities & -0.219 & 0.000 & -0.278 & 0.000 & -0.297 & 0.000 \\
\hline \multicolumn{7}{|l|}{ Parents' education: } \\
\hline parentaleducation2 & 0.083 & 0.174 & 0.113 & 0.135 & 0.119 & 0.134 \\
\hline parentaleducation3 & 0.102 & 0.062 & 0.125 & 0.062 & 0.119 & 0.089 \\
\hline parentaleducation 4 & 0.030 & 0.601 & 0.062 & 0.375 & 0.082 & 0.266 \\
\hline parentaleducation 5 & 0.065 & 0.274 & 0.073 & 0.309 & 0.098 & 0.199 \\
\hline parentaleducation6 & 0.058 & 0.379 & 0.063 & 0.433 & 0.068 & 0.430 \\
\hline parentaleducation7 & 0.082 & 0.279 & 0.117 & 0.209 & 0.146 & 0.137 \\
\hline \multicolumn{7}{|l|}{ Father's occupation: } \\
\hline entrepreneur & 0.102 & 0.151 & 0.133 & 0.125 & 0.118 & 0.197 \\
\hline professional worker & 0.134 & 0.054 & 0.187 & 0.029 & 0.168 & 0.065 \\
\hline own-account worker & 0.064 & 0.251 & 0.097 & 0.153 & 0.076 & 0.282 \\
\hline manager & 0.084 & 0.173 & 0.130 & 0.085 & 0.125 & 0.118 \\
\hline teacher/professor & -0.004 & 0.961 & 0.032 & 0.740 & 0.000 & 0.996 \\
\hline white collar high level & 0.145 & 0.011 & 0.177 & 0.011 & 0.157 & 0.035 \\
\hline white collar low level & 0.141 & 0.020 & 0.191 & 0.011 & 0.196 & 0.013 \\
\hline blue collar high level & 0.074 & 0.186 & 0.091 & 0.184 & 0.072 & 0.315 \\
\hline \multicolumn{7}{|l|}{ University Macro-regions: } \\
\hline North-East & -0.198 & 0.000 & -0.246 & 0.000 & -0.252 & 0.000 \\
\hline Centre & -0.308 & 0.000 & -0.403 & 0.000 & -0.436 & 0.000 \\
\hline South & -0.535 & 0.000 & -0.707 & 0.000 & -0.742 & 0.000 \\
\hline mass point 1 location & & & & & 0.000 & 0.000 \\
\hline mass point 1 probability & & & & & 0.263 & 0.000 \\
\hline mass point 2 location & & & & & 1.599 & 0.000 \\
\hline mass point 2 probability & & & & & 0.737 & 0.000 \\
\hline no of person-period obs & 25379 & & 25379 & & 25379 & \\
\hline Log-likelihood & -12220.758 & & -12212.685 & & -12195.428 & \\
\hline
\end{tabular}

Notes: Likelihood ratio statistic for testing zero gamma unobserved heterogeneity $=$ $16.144(\mathrm{P}$-value $=0)$. 
Table 2B: Results of the single risk model (men, sample 2001).

\begin{tabular}{|c|c|c|c|c|c|c|}
\hline \multirow[b]{2}{*}{ Variables } & \multicolumn{2}{|c|}{ Homogeneus } & \multicolumn{2}{|c|}{ Gamma Mixing } & \multicolumn{2}{|c|}{ Discrete Mixing } \\
\hline & Coefficient & $\mathrm{P}$-value & Coefficient & P-value & Coefficient & $\mathrm{P}$-value \\
\hline \multicolumn{7}{|l|}{ Duration dependence: } \\
\hline quarter 1 & 0.358 & 0.490 & 0.823 & 0.311 & -1.120 & 0.127 \\
\hline quarter 2 & -0.221 & 0.670 & 0.469 & 0.566 & -1.594 & 0.031 \\
\hline quarter 3 & -0.302 & 0.562 & 0.540 & 0.511 & -1.582 & 0.033 \\
\hline quarter 4 & -0.028 & 0.958 & 0.968 & 0.240 & -1.199 & 0.107 \\
\hline quarter 5 & 0.118 & 0.821 & 1.287 & 0.121 & -0.908 & 0.225 \\
\hline quarter 6 & 0.100 & 0.848 & 1.447 & 0.083 & -0.739 & 0.327 \\
\hline quarter 7 & 0.125 & 0.810 & 1.646 & 0.051 & -0.488 & 0.521 \\
\hline quarter 8 & 0.200 & 0.702 & 1.902 & 0.025 & -0.148 & 0.847 \\
\hline quarter 9 & 0.450 & 0.389 & 2.364 & 0.006 & 0.405 & 0.597 \\
\hline quarter 10 & 0.614 & 0.242 & 2.780 & 0.002 & 0.828 & 0.274 \\
\hline quarter 11 & 0.826 & 0.117 & 3.290 & 0.000 & 1.191 & 0.111 \\
\hline quarter 12 & 1.490 & 0.005 & 4.486 & 0.000 & 1.943 & 0.009 \\
\hline \multicolumn{7}{|l|}{ Personal characteristics: } \\
\hline graduation in due time & 0.002 & 0.974 & -0.019 & 0.861 & -0.073 & 0.434 \\
\hline mobility & 0.011 & 0.751 & 0.009 & 0.865 & 0.007 & 0.871 \\
\hline military service & -0.368 & 0.000 & -0.792 & 0.000 & -0.734 & 0.000 \\
\hline age & -0.030 & 0.034 & -0.036 & 0.106 & -0.030 & 0.132 \\
\hline workduruniversity & -0.058 & 0.066 & -0.100 & 0.043 & -0.106 & 0.014 \\
\hline \multicolumn{7}{|l|}{ Academic performance: } \\
\hline university final mark & -0.005 & 0.033 & -0.004 & 0.208 & -0.007 & 0.022 \\
\hline high school final mark & 0.001 & 0.744 & 0.001 & 0.726 & 0.001 & 0.784 \\
\hline general high school & 0.023 & 0.763 & 0.025 & 0.831 & -0.064 & 0.542 \\
\hline vocational/tech high school & 0.044 & 0.563 & 0.061 & 0.608 & -0.004 & 0.971 \\
\hline engineering & 0.152 & 0.001 & 0.140 & 0.042 & 0.153 & 0.010 \\
\hline social sciences & -0.123 & 0.004 & -0.265 & 0.000 & -0.198 & 0.001 \\
\hline humanities & -0.342 & 0.000 & -0.671 & 0.000 & -0.537 & 0.000 \\
\hline \multicolumn{7}{|l|}{ Parents' education: } \\
\hline parentaleducation2 & 0.077 & 0.222 & 0.183 & 0.061 & 0.104 & 0.206 \\
\hline parentaleducation3 & 0.058 & 0.322 & 0.092 & 0.310 & 0.101 & 0.215 \\
\hline parentaleducation4 & 0.025 & 0.680 & 0.011 & 0.902 & 0.042 & 0.608 \\
\hline parentaleducation 5 & 0.059 & 0.352 & 0.050 & 0.611 & 0.100 & 0.250 \\
\hline parentaleducation6 & -0.150 & 0.033 & -0.261 & 0.016 & -0.160 & 0.098 \\
\hline parentaleducation7 & 0.039 & 0.620 & 0.103 & 0.400 & 0.113 & 0.286 \\
\hline \multicolumn{7}{|l|}{ Father's occupation: } \\
\hline entrepreneur & 0.039 & 0.609 & 0.232 & 0.062 & 0.156 & 0.126 \\
\hline professional worker & -0.079 & 0.290 & -0.051 & 0.656 & -0.077 & 0.449 \\
\hline own-account worker & -0.019 & 0.749 & -0.017 & 0.858 & -0.007 & 0.930 \\
\hline manager & 0.125 & 0.055 & 0.270 & 0.008 & 0.172 & 0.045 \\
\hline teacher/professor & -0.093 & 0.260 & -0.111 & 0.376 & -0.165 & 0.131 \\
\hline white collar high level & -0.031 & 0.618 & 0.004 & 0.967 & -0.027 & 0.744 \\
\hline white collar low level & -0.010 & 0.879 & 0.042 & 0.681 & 0.007 & 0.932 \\
\hline blue collar high level & -0.027 & 0.657 & -0.034 & 0.717 & -0.047 & 0.562 \\
\hline \multicolumn{7}{|l|}{ University Macro-regions: } \\
\hline North-East & -0.052 & 0.223 & -0.101 & 0.131 & -0.090 & 0.112 \\
\hline Centre & -0.190 & 0.000 & -0.365 & 0.000 & -0.287 & 0.000 \\
\hline South & -0.356 & 0.000 & -0.657 & 0.000 & -0.533 & 0.000 \\
\hline mass point 1 location & & & & & 0.000 & 0.000 \\
\hline mass point 1 probability & & & & & 0.220 & 0.000 \\
\hline mass point 2 location & & & & & 2.160 & 0.000 \\
\hline mass point 2 probability & & & & & 0.779 & 0.000 \\
\hline no of person-period obs & 20553 & & 20553 & & 20553 & \\
\hline Log-likelihood & -10393.897 & & -10360.256 & & -10331.334 & \\
\hline
\end{tabular}

Notes: Likelihood ratio statistic for testing zero gamma unobserved heterogeneity $=$ $67.281(\mathrm{P}$-value $=0)$. 
Table 3B: Results of the single risk model (Centre-South, sample 2001).

\begin{tabular}{|c|c|c|c|c|c|c|}
\hline \multirow[b]{2}{*}{ Variables } & \multicolumn{2}{|c|}{ Homogeneus } & \multicolumn{2}{|c|}{ Gamma Mixing } & \multicolumn{2}{|c|}{ Discrete Mixing } \\
\hline & Coefficient & P-value & Coefficient & P-value & Coefficient & P-value \\
\hline \multicolumn{7}{|l|}{ Duration dependence: } \\
\hline quarter 1 & -0.822 & 0.129 & -0.823 & 0.130 & -2.697 & 0.001 \\
\hline quarter 2 & -1.164 & 0.032 & -1.164 & 0.033 & -2.983 & 0.000 \\
\hline quarter 3 & -1.164 & 0.032 & -1.164 & 0.033 & -2.925 & 0.000 \\
\hline quarter 4 & -1.067 & 0.050 & -1.066 & 0.052 & -2.761 & 0.000 \\
\hline quarter 5 & -0.951 & 0.081 & -0.950 & 0.083 & -2.562 & 0.001 \\
\hline quarter 6 & -0.932 & 0.087 & -0.930 & 0.091 & -2.440 & 0.002 \\
\hline quarter 7 & -0.921 & 0.091 & -0.919 & 0.097 & -2.308 & 0.003 \\
\hline quarter 8 & -0.602 & 0.269 & -0.599 & 0.280 & -1.824 & 0.020 \\
\hline quarter 9 & -0.502 & 0.357 & -0.498 & 0.373 & -1.501 & 0.053 \\
\hline quarter 10 & -0.360 & 0.511 & -0.355 & 0.530 & -1.108 & 0.146 \\
\hline quarter 11 & 0.006 & 0.991 & 0.012 & 0.984 & -0.497 & 0.503 \\
\hline quarter 12 & 0.720 & 0.188 & 0.728 & 0.219 & 0.390 & 0.593 \\
\hline \multicolumn{7}{|l|}{ Personal characteristics: } \\
\hline gender & -0.166 & 0.000 & -0.167 & 0.000 & -0.216 & 0.000 \\
\hline graduation in due time & -0.109 & 0.152 & -0.109 & 0.153 & -0.091 & 0.342 \\
\hline mobility & 0.041 & 0.231 & 0.042 & 0.235 & 0.037 & 0.416 \\
\hline military service & -0.285 & 0.000 & -0.286 & 0.000 & -0.498 & 0.000 \\
\hline age & -0.030 & 0.025 & -0.030 & 0.026 & -0.022 & 0.216 \\
\hline workduruniversity & -0.161 & 0.000 & -0.162 & 0.000 & -0.214 & 0.000 \\
\hline \multicolumn{7}{|l|}{ Academic performance: } \\
\hline university final mark & 0.001 & 0.624 & 0.001 & 0.625 & 0.003 & 0.361 \\
\hline high school final mark & 0.002 & 0.499 & 0.002 & 0.500 & 0.001 & 0.784 \\
\hline general high school & 0.064 & 0.257 & 0.064 & 0.259 & 0.065 & 0.380 \\
\hline vocational/tech high school & 0.051 & 0.402 & 0.052 & 0.404 & 0.078 & 0.331 \\
\hline engineering & 0.142 & 0.005 & 0.142 & 0.006 & 0.173 & 0.010 \\
\hline social sciences & -0.184 & 0.000 & -0.185 & 0.000 & -0.276 & 0.000 \\
\hline humanities & -0.329 & 0.000 & -0.331 & 0.000 & -0.461 & 0.000 \\
\hline \multicolumn{7}{|l|}{ Parents' education: } \\
\hline parentaleducation2 & 0.069 & 0.291 & 0.070 & 0.303 & 0.133 & 0.121 \\
\hline parentaleducation3 & 0.047 & 0.428 & 0.047 & 0.432 & 0.081 & 0.298 \\
\hline parentaleducation4 & 0.090 & 0.145 & 0.091 & 0.152 & 0.186 & 0.024 \\
\hline parentaleducation5 & 0.104 & 0.106 & 0.105 & 0.111 & 0.175 & 0.043 \\
\hline parentaleducation6 & 0.045 & 0.527 & 0.045 & 0.529 & 0.123 & 0.198 \\
\hline parentaleducation7 & 0.212 & 0.008 & 0.213 & 0.011 & 0.419 & 0.000 \\
\hline \multicolumn{7}{|l|}{ Father's occupation: } \\
\hline entrepreneur & -0.097 & 0.245 & -0.097 & 0.249 & -0.060 & 0.576 \\
\hline professional worker & -0.058 & 0.457 & -0.058 & 0.458 & -0.139 & 0.175 \\
\hline own-account worker & 0.044 & 0.463 & 0.044 & 0.464 & 0.065 & 0.402 \\
\hline manager & 0.066 & 0.334 & 0.067 & 0.341 & 0.040 & 0.660 \\
\hline teacher/professor & -0.129 & 0.106 & -0.129 & 0.108 & -0.284 & 0.008 \\
\hline white collar high level & 0.052 & 0.402 & 0.053 & 0.404 & 0.046 & 0.570 \\
\hline white collar low level & 0.111 & 0.079 & 0.112 & 0.083 & 0.114 & 0.167 \\
\hline blue collar high level & 0.091 & 0.137 & 0.091 & 0.138 & 0.037 & 0.639 \\
\hline mass point 1 location & & & & & 0.000 & 0.000 \\
\hline mass point 1 probability & & & & & 0.270 & 0.000 \\
\hline mass point 2 location & & & & & 1.823 & 0.000 \\
\hline mass point 2 probability & & & & & 0.729 & 0.000 \\
\hline no of person-period obs & 23343 & & 23343 & & 23343 & \\
\hline Log-likelihood & -10604.409 & & -10604.408 & & -10590.638 & \\
\hline
\end{tabular}

Notes: Likelihood ratio statistic for testing zero gamma unobserved heterogeneity $=$ $0.001(\mathrm{P}$-value $=0.969)$. 
Table 4B: Results of the single risk model (North, sample 2001).

\begin{tabular}{|c|c|c|c|c|c|c|}
\hline \multirow[b]{2}{*}{ Variables } & \multicolumn{2}{|c|}{ Homogeneus } & \multicolumn{2}{|c|}{ Gamma Mixing } & \multicolumn{2}{|c|}{ Discrete Mixing } \\
\hline & Coefficient & $\mathrm{P}$-value & Coefficient & $\mathrm{P}$-value & Coefficient & $\mathrm{P}$-value \\
\hline \multicolumn{7}{|l|}{ Duration dependence: } \\
\hline quarter 1 & 1.338 & 0.004 & 1.338 & 0.002 & 0.626 & 0.324 \\
\hline quarter 2 & 0.862 & 0.062 & 0.862 & 0.051 & 0.279 & 0.662 \\
\hline quarter 3 & 0.754 & 0.103 & 0.754 & 0.088 & 0.292 & 0.650 \\
\hline quarter 4 & 0.852 & 0.065 & 0.852 & 0.054 & 0.528 & 0.413 \\
\hline quarter 5 & 1.052 & 0.023 & 1.052 & 0.017 & 0.922 & 0.156 \\
\hline quarter 6 & 0.930 & 0.045 & 0.930 & 0.036 & 1.056 & 0.108 \\
\hline quarter 7 & 0.989 & 0.033 & 0.989 & 0.026 & 1.419 & 0.032 \\
\hline quarter 8 & 0.998 & 0.032 & 0.998 & 0.025 & 1.752 & 0.008 \\
\hline quarter 9 & 1.310 & 0.005 & 1.310 & 0.003 & 2.356 & 0.000 \\
\hline quarter 10 & 1.324 & 0.005 & 1.324 & 0.003 & 2.531 & 0.000 \\
\hline quarter 11 & 1.616 & 0.001 & 1.616 & 0.000 & 2.876 & 0.000 \\
\hline quarter 12 & 2.270 & 0.000 & 2.270 & 0.000 & 3.566 & 0.000 \\
\hline \multicolumn{7}{|l|}{ Personal characteristics: } \\
\hline gender & -0.139 & 0.000 & -0.139 & 0.000 & -0.228 & 0.000 \\
\hline graduation in due time & -0.113 & 0.032 & -0.113 & 0.032 & -0.194 & 0.005 \\
\hline mobility & 0.001 & 0.975 & 0.001 & 0.975 & -0.033 & 0.447 \\
\hline military service & -0.470 & 0.000 & -0.470 & 0.000 & -0.959 & 0.000 \\
\hline age & -0.069 & 0.000 & -0.069 & 0.000 & -0.107 & 0.000 \\
\hline workduruniversity & -0.058 & 0.048 & -0.058 & 0.047 & -0.110 & 0.005 \\
\hline \multicolumn{7}{|l|}{ Academic performance: } \\
\hline university final mark & -0.006 & 0.007 & -0.006 & 0.007 & -0.007 & 0.012 \\
\hline high school final mark & 0.002 & 0.306 & 0.002 & 0.308 & 0.003 & 0.282 \\
\hline general high school & 0.048 & 0.316 & 0.048 & 0.316 & 0.018 & 0.782 \\
\hline vocational/tech high school & 0.086 & 0.097 & 0.086 & 0.097 & 0.085 & 0.227 \\
\hline engineering & 0.196 & 0.000 & 0.196 & 0.000 & 0.309 & 0.000 \\
\hline social sciences & -0.033 & 0.407 & -0.033 & 0.406 & -0.036 & 0.502 \\
\hline humanities & -0.200 & 0.000 & -0.200 & 0.000 & -0.300 & 0.000 \\
\hline \multicolumn{7}{|l|}{ Parents' education: } \\
\hline parentaleducation2 & 0.098 & 0.096 & 0.098 & 0.096 & 0.117 & 0.134 \\
\hline parentaleducation 3 & 0.124 & 0.021 & 0.124 & 0.021 & 0.108 & 0.145 \\
\hline parentaleducation4 & 0.023 & 0.677 & 0.023 & 0.677 & 0.017 & 0.818 \\
\hline parentaleducation 5 & 0.073 & 0.205 & 0.073 & 0.204 & 0.076 & 0.324 \\
\hline parentaleducation6 & -0.046 & 0.477 & -0.046 & 0.478 & -0.070 & 0.426 \\
\hline parentaleducation7 & 0.015 & 0.838 & 0.015 & 0.838 & -0.014 & 0.886 \\
\hline \multicolumn{7}{|l|}{ Father's occupation: } \\
\hline entrepreneur & 0.156 & 0.020 & 0.156 & 0.020 & 0.240 & 0.010 \\
\hline professional worker & 0.094 & 0.165 & 0.094 & 0.166 & 0.183 & 0.044 \\
\hline own-account worker & 0.033 & 0.554 & 0.033 & 0.554 & 0.066 & 0.383 \\
\hline manager & 0.134 & 0.024 & 0.134 & 0.025 & 0.244 & 0.002 \\
\hline teacher/professor & -0.032 & 0.700 & -0.032 & 0.701 & 0.030 & 0.789 \\
\hline white collar high level & 0.089 & 0.120 & 0.089 & 0.120 & 0.142 & 0.069 \\
\hline white collar low level & 0.048 & 0.443 & 0.048 & 0.443 & 0.144 & 0.091 \\
\hline blue collar high level & 0.034 & 0.544 & 0.034 & 0.545 & 0.071 & 0.359 \\
\hline mass point 1 location & & & & & 0.000 & 0.000 \\
\hline mass point 1 probability & & & & & 0.240 & 0.000 \\
\hline mass point 2 location & & & & & 2.265 & 0.000 \\
\hline mass point 2 probability & & & & & 0.759 & 0.000 \\
\hline no of person-period obs & 23097 & & 23097 & & 23097 & \\
\hline Log-likelihood & -12242.230 & & -12242.230 & & -12182.990 & \\
\hline
\end{tabular}

Notes: Likelihood ratio statistic for testing zero gamma unobserved heterogeneity $=$ $0.001(\mathrm{P}$-value $=0.969)$. 
Table 5B: Results of the single risk model (sample 2004).

\begin{tabular}{|c|c|c|c|c|c|c|}
\hline \multirow[b]{2}{*}{ Variables } & \multicolumn{2}{|c|}{ Homogeneus } & \multicolumn{2}{|c|}{ Gamma Mixing } & \multicolumn{2}{|c|}{ Discrete Mixing } \\
\hline & Coefficient & $\mathrm{P}$-value & Coefficient & P-value & Coefficient & $\mathrm{P}$-value \\
\hline \multicolumn{7}{|l|}{ Duration dependence: } \\
\hline quarter 1 & -1.261 & 0.000 & -1.249 & 0.000 & -2.559 & 0.000 \\
\hline quarter 2 & -1.463 & 0.000 & -1.283 & 0.000 & -2.725 & 0.000 \\
\hline quarter 3 & -1.533 & 0.000 & -1.212 & 0.000 & -2.753 & 0.000 \\
\hline quarter 4 & -1.458 & 0.000 & -1.000 & 0.000 & -2.628 & 0.000 \\
\hline quarter 5 & -1.509 & 0.000 & -0.918 & 0.000 & -2.618 & 0.000 \\
\hline quarter 6 & -1.476 & 0.000 & -0.757 & 0.005 & -2.514 & 0.000 \\
\hline quarter 7 & -1.598 & 0.000 & -0.760 & 0.008 & -2.559 & 0.000 \\
\hline quarter 8 & -1.354 & 0.000 & -0.387 & 0.199 & -2.219 & 0.000 \\
\hline quarter 9 & -1.169 & 0.000 & -0.046 & 0.887 & -1.901 & 0.000 \\
\hline quarter 10 & -0.910 & 0.000 & 0.404 & 0.258 & -1.462 & 0.000 \\
\hline quarter 11 & -0.383 & 0.041 & 1.228 & 0.003 & -0.667 & 0.009 \\
\hline quarter 12 & 0.032 & 0.867 & 2.147 & 0.000 & -0.023 & 0.916 \\
\hline \multicolumn{7}{|l|}{ Personal characteristics: } \\
\hline gender & -0.046 & 0.072 & -0.075 & 0.028 & -0.061 & 0.039 \\
\hline graduation in due time & 0.068 & 0.035 & 0.133 & 0.002 & 0.102 & 0.005 \\
\hline mobility & -0.026 & 0.303 & -0.067 & 0.048 & -0.051 & 0.076 \\
\hline age & 0.013 & 0.430 & 0.027 & 0.211 & 0.022 & 0.254 \\
\hline workduruniversity & -0.141 & 0.000 & -0.164 & 0.000 & -0.147 & 0.000 \\
\hline \multicolumn{7}{|l|}{ Academic performance: } \\
\hline university final mark & -0.022 & 0.042 & -0.027 & 0.059 & -0.023 & 0.061 \\
\hline high school final mark & 0.005 & 0.004 & 0.007 & 0.003 & 0.006 & 0.007 \\
\hline general high school & 0.162 & 0.002 & 0.164 & 0.017 & 0.151 & 0.012 \\
\hline vocational/tech high school & 0.186 & 0.001 & 0.222 & 0.002 & 0.197 & 0.002 \\
\hline engineering & 0.273 & 0.000 & 0.325 & 0.000 & 0.284 & 0.000 \\
\hline social sciences & -0.044 & 0.185 & -0.059 & 0.178 & -0.055 & 0.150 \\
\hline humanities & -0.182 & 0.000 & -0.277 & 0.000 & -0.243 & 0.000 \\
\hline \multicolumn{7}{|l|}{ Parents' education: } \\
\hline parentaleducation2 & 0.114 & 0.025 & 0.131 & 0.049 & 0.122 & 0.035 \\
\hline parentaleducation3 & 0.092 & 0.053 & 0.102 & 0.100 & 0.100 & 0.067 \\
\hline parentaleducation4 & 0.150 & 0.001 & 0.174 & 0.005 & 0.164 & 0.002 \\
\hline parentaleducation 5 & 0.105 & 0.034 & 0.117 & 0.071 & 0.120 & 0.033 \\
\hline parentaleducation6 & 0.127 & 0.019 & 0.161 & 0.024 & 0.146 & 0.018 \\
\hline parentaleducation7 & 0.132 & 0.033 & 0.159 & 0.050 & 0.147 & 0.036 \\
\hline \multicolumn{7}{|l|}{ Father's occupation: } \\
\hline entrepreneur & 0.150 & 0.085 & 0.316 & 0.007 & 0.239 & 0.017 \\
\hline professional worker & 0.077 & 0.370 & 0.162 & 0.155 & 0.124 & 0.219 \\
\hline own-account worker & 0.065 & 0.418 & 0.098 & 0.346 & 0.077 & 0.401 \\
\hline manager & 0.005 & 0.957 & 0.059 & 0.587 & 0.032 & 0.739 \\
\hline teacher/professor & 0.003 & 0.974 & 0.034 & 0.751 & 0.008 & 0.936 \\
\hline white collar high level & 0.003 & 0.971 & 0.062 & 0.545 & 0.036 & 0.696 \\
\hline white collar low level & 0.025 & 0.755 & 0.074 & 0.486 & 0.042 & 0.656 \\
\hline blue collar high level & 0.015 & 0.852 & 0.049 & 0.637 & 0.023 & 0.798 \\
\hline \multicolumn{7}{|l|}{ University Macro-regions: } \\
\hline North-East & -0.078 & 0.041 & -0.117 & 0.021 & -0.101 & 0.021 \\
\hline Centre & -0.160 & 0.000 & -0.227 & 0.000 & -0.194 & 0.000 \\
\hline South & -0.385 & 0.000 & -0.564 & 0.000 & -0.475 & 0.000 \\
\hline mass point 1 location & & & & & 0.000 & 0.000 \\
\hline mass point 1 probability & & & & & 0.130 & 0.000 \\
\hline mass point 2 location & & & & & 1.412 & 0.000 \\
\hline mass point 2 probability & & & & & 0.869 & 0.000 \\
\hline no of person-period obs & 29260 & & 29260 & & 29260 & \\
\hline Log-likelihood & -16593.319 & & -16572.680 & & -16573.635 & \\
\hline
\end{tabular}

Notes: Likelihood ratio statistic for testing zero gamma unobserved heterogeneity $=$ $41.278(\mathrm{P}$-value $=0)$. 
Department of Economics:

Skriftserie/Working Paper:

2003:

WP 03-1 Søren Harck: Er der nu en strukturelt bestemt langsigts-ledighed i SMEC?: Phillipskurven i SMEC 99 vis-à-vis SMEC 94. ISSN 1397-4831.

WP 03-2 Beatrice Schindler Rangvid: Evaluating Private School Quality in Denmark. ISSN 1397-4831.

WP 03-3 Tor Eriksson: Managerial Pay and Executive Turnover in the Czech and Slovak Republics. ISSN 1397-4831.

WP 03-4 Michael Svarer and Mette Verner: Do Children Stabilize Marriages? ISSN 1397-4831.

WP 03-5 Christian Bjørnskov and Gert Tinggaard Svendsen: Measuring social capital - Is there a single underlying explanation? ISSN 1397-4831.

WP 03-6 Vibeke Jakobsen and Nina Smith: The educational attainment of the children of the Danish 'guest worker' immigrants. ISSN 1397-4831.

WP 03-7 Anders Poulsen: The Survival and Welfare Implications of Altruism When Preferences are Endogenous. ISSN 1397-4831.

WP 03-8 Helena Skyt Nielsen and Mette Verner: Why are Well-educated Women not Full-timers? ISSN 1397-4831.

WP 03-9 Anders Poulsen: On Efficiency, Tie-Breaking Rules and Role Assignment Procedures in Evolutionary Bargaining. ISSN 13974831.

WP 03-10 Anders Poulsen and Gert Tinggaard Svendsen: Rise and Decline of Social Capital

- Excess Co-operation in the One-Shot Prisoner's Dilemma Game. ISSN 1397-4831. 
WP 03-11 Nabanita Datta Gupta and Amaresh Dubey: Poverty and Fertility: An Instrumental Variables Analysis on Indian Micro Data. ISSN 1397-4831.

WP 03-12 Tor Eriksson: The Managerial Power Impact on Compensation Some Further Evidence. ISSN 1397-4831.

WP 03-13 Christian Bjørnskov: Corruption and Social Capital. ISSN 13974831.

WP 03-14 Debashish Bhattacherjee: The Effects of Group Incentives in an Indian Firm

- Evidence from Payroll Data. ISSN 1397-4831.

WP 03-15 Tor Eriksson och Peter Jensen: Tidsbegränsade anställninger danska erfarenheter. ISSN 1397-4831.

WP 03-16 Tom Coupé, Valérie Smeets and Frédéric Warzynski: Incentives, Sorting and Productivity along the Career: Evidence from a Sample of Top Economists. ISSN 1397-4831.

WP 03-17 Jozef Koning, Patrick Van Cayseele and Frédéric Warzynski: The Effects of Privatization and Competitive Pressure on Firms' Price-Cost Margins: Micro Evidence from Emerging Economies. ISSN 1397-4831.

WP 03-18 Urs Steiner Brandt and Gert Tinggaard Svendsen: The coalition of industrialists and environmentalists in the climate change issue. ISSN 1397-4831.

WP 03-19 Jan Bentzen: An empirical analysis of gasoline price convergence for 20 OECD countries. ISSN 1397-4831.

WP 03-20 Jan Bentzen and Valdemar Smith: Regional income convergence in the Scandinavian countries. ISSN 1397-4831.

WP 03-21 Gert Tinggaard Svendsen: Social Capital, Corruption and Economic Growth: Eastern and Western Europe. ISSN 13974831.

WP 03-22 Jan Bentzen and Valdemar Smith: A Comparative Study of Wine Auction Prices: Mouton Rothschild Premier Cru Classé. ISSN 1397-4831. 
WP 03-23 Peter Guldager: Folkepensionisternes incitamenter til at arbejde. ISSN 1397-4831.

WP 03-24 Valérie Smeets and Frédéric Warzynski: Job Creation, Job Destruction and Voting Behavior in Poland. ISSN 1397-4831.

WP 03-25 Tom Coupé, Valérie Smeets and Frédéric Warzynski: Incentives in Economic Departments: Testing Tournaments? ISSN 13974831.

WP 03-26 Erik Strøjer Madsen, Valdemar Smith and Mogens DillingHansen: Industrial clusters, firm location and productivity Some empirical evidence for Danish firms. ISSN 1397-4831.

WP 03-27 Aycan Çelikaksoy, Helena Skyt Nielsen and Mette Verner: Marriage Migration: Just another case of positive assortative matching? ISSN 1397-4831.

2004:

WP 04-1 Elina Pylkkänen and Nina Smith: Career Interruptions due to Parental Leave - A Comparative Study of Denmark and Sweden. ISSN 1397-4831.

WP 04-2 Urs Steiner Brandt and Gert Tinggaard Svendsen: Switch Point and First-Mover Advantage: The Case of the Wind Turbine Industry. ISSN 1397-4831.

WP 04-3 Tor Eriksson and Jaime Ortega: The Adoption of Job Rotation: Testing the Theories. ISSN 1397-4831.

WP 04-4 Valérie Smeets: Are There Fast Tracks in Economic Departments? Evidence from a Sample of Top Economists. ISSN 1397-4831.

WP 04-5 Karsten Bjerring Olsen, Rikke Ibsen and Niels WestergaardNielsen: Does Outsourcing Create Unemployment? The Case of the Danish Textile and Clothing Industry. ISSN 1397-4831.

WP 04-6 Tor Eriksson and Johan Moritz Kuhn: Firm Spin-offs in Denmark 1981-2000 - Patterns of Entry and Exit. ISSN 13974831. 
WP 04-7 Mona Larsen and Nabanita Datta Gupta: The Impact of Health on Individual Retirement Plans: a Panel Analysis comparing Self-reported versus Diagnostic Measures. ISSN 1397-4831.

WP 04-8 Christian Bjørnskov: Inequality, Tolerance, and Growth. ISSN 1397-4831.

WP 04-9 Christian Bjørnskov: Legal Quality, Inequality, and Tolerance. ISSN 1397-4831.

WP 04-10 Karsten Bjerring Olsen: Economic Cooperation and Social Identity: Towards a Model of Economic Cross-Cultural Integration. ISSN 1397-4831.

WP 04-11 Iben Bolvig: Within- and between-firm mobility in the low-wage labour market. ISSN 1397-4831.

WP 04-12 Odile Poulsen and Gert Tinggaard Svendsen: Social Capital and Market Centralisation: A Two-Sector Model. ISSN 1397-4831.

WP 04-13 Aditya Goenka and Odile Poulsen: Factor Intensity Reversal and Ergodic Chaos. ISSN 1397-4831.

WP 04-14 Jan Bentzen and Valdemar Smith: Short-run and long-run relationships in the consumption of alcohol in the Scandinavian countries.

ISBN 87-7882-010-3 (print); ISBN 87-7882-011-1 (online).

WP 04-15 Jan Bentzen, Erik Strøjer Madsen, Valdemar Smith and Mogens Dilling-Hansen: Persistence in Corporate Performance? Empirical Evidence from Panel Unit Root Tests.

ISBN 87-7882-012-X (print); ISBN 87-7882-013-8 (online).

WP 04-16 Anders U. Poulsen and Jonathan H.W. Tan: Can Information Backfire? Experimental Evidence from the Ultimatum Game. ISBN 87-7882-014-6 (print); ISBN 87-7882-015-4 (online).

WP 04-17 Werner Roeger and Frédéric Warzynski: A Joint Estimation of Price-Cost Margins and Sunk Capital: Theory and Evidence from the European Electricity Industry.

ISBN 87-7882-016-2 (print); ISBN 87-7882-017-0 (online). 
WP 04-18 Nabanita Datta Gupta and Tor Eriksson: New workplace practices and the gender wage gap.

ISBN 87-7882-018-9 (print); ISBN 87-7882-019-7 (online).

WP 04-19 Tor Eriksson and Axel Werwatz: The Prevalence of Internal Labour Markets - New Evidence from Panel Data.

ISBN 87-7882-020-0 (print); ISBN 87-7882-021-9 (online).

WP 04-20 Anna Piil Damm and Michael Rosholm: Employment Effects of Dispersal Policies on Refugee Immigrants: Empirical Evidence. ISBN 87-7882-022-7 (print); ISBN 87-7882-023-5 (online).

2005:

WP 05-1 Anna Piil Damm and Michael Rosholm: Employment Effects of Dispersal Policies on Refugee Immigrants: Theory.

ISBN 87-7882-024-3 (print); ISBN 87-7882-025-1 (online).

WP 05-2 Anna Piil Damm: Immigrants’ Location Preferences: Exploiting a Natural Experiment.

ISBN 87-7882-036-7 (print); ISBN 87-7882-037-5 (online).

WP 05-3 Anna Piil Damm: The Danish Dispersal Policy on Refugee Immigrants 1986-1998: A Natural Experiment? ISBN 87-7882-038-3 (print); ISBN 87-7882-039-1 (online).

WP 05-4 Rikke Ibsen and Niels Westergaard-Nielsen: Job Creation and Destruction over the Business Cycles and the Impact on Individual Job Flows in Denmark 1980-2001.

ISBN 87-7882-040-5 (print); ISBN 87-7882-041-3 (online).

WP 05-5 Anna Maria Kossowska, Nina Smith, Valdemar Smith and Mette Verner: Til gavn for bundlinjen - Forbedrer kvinder i topledelse og bestyrelse danske virksomheders bundlinje?

ISBN 87-7882-042-1 (print); ISBN 87-7882-043-X (online).

WP 05-6 Odile Poulsen and Gert Tinggaard Svendsen: The Long and Winding Road: Social Capital and Commuting.

ISBN 87-7882-044-8 (print); ISBN 87-7882-045-6 (online).

WP 05-7 Odile Poulsen and Gert Tinggaard Svendsen: Love Thy Neighbor: Bonding versus Bridging Trust.

ISBN 87-7882-062-6 (print); ISBN 87-7882-063-4 (online). 
WP 05-8 Christian Bjørnskov: Political Ideology and Economic Freedom. ISBN 87-7882-064-2 (print); ISBN 87-7882-065-0 (online).

WP 05-9 Sebastian Buhai and Coen Teulings: Tenure Profiles and Efficient Separation in a Stochastic Productivity Model. ISBN 87-7882-066-9 (print); ISBN 87-7882-067-7 (online).

WP 05-10 Christian Grund and Niels Westergård-Nielsen: Age Structure of the Workforce and Firm Performance.

ISBN 87-7882-068-5 (print); ISBN 87-7882-069-3 (online).

WP 05-11 Søren Harck: AD-AS på dansk.

ISBN 87-7882-070-7 (print); ISBN 87-7882-071-5 (online).

WP 05-12 Søren Harck: Hviler Dansk Økonomi på en Cobb-Douglas teknologi?

ISBN 87-7882-092-8 (print); ISBN 87-7882-093-6 (online).

2006:

WP 06-1 Nicolai Kristensen and Edvard Johansson: New Evidence on Cross-Country Differences in Job Satisfaction Using Anchoring Vignettes.

ISBN 87-7882-094-4 (print); ISBN 87-7882-095-2 (online).

WP 06-2 Christian Bjørnskov: How Does Social Trust Affect Economic Growth?

ISBN 87-7882-096-0 (print); ISBN 87-7882-097-9 (online).

WP 06-3 Jan Bentzen, Erik Strøjer Madsen and Valdemar Smith: The Growth Opportunities for SMEs?

ISBN 87-7882-098-7 (print); ISBN 87-7882-099-5 (online).

WP 06-4 Anna Piil Damm: Ethnic Enclaves and Immigrant Labour Market Outcomes: Quasi-Experimental Evidence. ISBN 87-7882-100-2 (print); ISBN 87-7882-101-0 (online).

WP 06-5 Svend Jespersen, Nicolai Kristensen og Lars Skipper: En kritik af VEU-udvalgets arbejde.

ISBN 87-7882-159-2 (print); ISBN 87-7882-160-6 (online).

WP 06-6 Kræn Blume and Mette Verner: Welfare Dependency among Danish Immigrants.

ISBN 87-7882-161-4 (print); ISBN 87-7882-162-2 (online). 
WP 06-7 Jürgen Bitzer, Wolfram Schrettl and Philipp J.H. Schröder: Intrinsic Motivation versus Signaling in Open Source Software Development. ISBN 87-7882-163-0 (print); ISBN 87-7882-164-9 (online).

WP 06-8 Valérie Smeets, Kathryn Ierulli and Michael Gibbs: Mergers of Equals \& Unequals.

ISBN 87-7882-165-7 (print); ISBN 87-7882-166-5 (online).

WP 06-9 Valérie Smeets: Job Mobility and Wage Dynamics.

ISBN 87-7882-167-3 (print); ISBN 87-7882-168-1 (online).

WP 06-10 Valérie Smeets and Frédéric Warzynski: Testing Models of Hierarchy: Span of Control, Compensation and Career Dynamics.

ISBN 87-7882-187-8 (print); ISBN 87-7882-188-6 (online).

WP 06-11 Sebastian Buhai and Marco van der Leij: A Social Network Analysis of Occupational Segregation.

ISBN 87-7882-189-4 (print); ISBN 87-7882-190-8 (online).

2007:

WP 07-1 Christina Bjerg, Christian Bjørnskov and Anne Holm: Growth, Debt Burdens and Alleviating Effects of Foreign Aid in Least Developed Countries.

ISBN 87-7882-191-6 (print); ISBN 87-7882-192-4 (online).

WP 07-2 Jeremy T. Fox and Valérie Smeets: Do Input Quality and Structural Productivity Estimates Drive Measured Differences in Firm Productivity?

ISBN 87-7882-193-2 (print); ISBN 87-7882-194-0 (online).

WP 07-3 Elisabetta Trevisan: Job Security and New Restrictive Permanent Contracts. Are Spanish Workers More Worried of Losing Their Job?

ISBN 87-7882-195-9 (print); ISBN 87-7882-196-7 (online).

WP 07-4 Tor Eriksson and Jaime Ortega: Performance Pay and the "Time Squeeze”.

ISBN 9788778822079 (print); ISBN 9788778822086 (online). 
WP 07-5 Johan Moritz Kuhn: My Pay is Too Bad (I Quit). Your Pay is Too Good (You're Fired).

ISBN 9788778822093 (print); ISBN 9788778822109 (online).

WP 07-6 Christian Bjørnskov: Social trust and the growth of schooling. ISBN 9788778822116 (print); ISBN 9788778822123 (online).

WP 07-7 Jan Bentzen and Valdemar Smith: Explaining champagne prices in Scandinavia - what is the best predictor?

ISBN 9788778822130 (print); ISBN 9788778822147 (online).

WP 07-8 Sandra Cavaco, Jean-Michel Etienne and Ali Skalli: Identifying causal paths between health and socio-economic status:

Evidence from European older workforce surveys ISBN 9788778822154 (print); ISBN 9788778822161 (online).

WP 07-9 Søren Harck: Long-run properties of some Danish macroeconometric models: an analytical approach.

ISBN 9788778822390 (print); ISBN 9788778822406 (online).

WP 07-10 Takao Kato and Hideo Owan: Market Characteristics, Intra-Firm Coordination, and the Choice of Human Resource Management Systems: Evidence from New Japanese Data.

ISBN 9788778822413 (print); ISBN 9788778822420 (online).

WP 07-11 Astrid Würtz: The Long-Term Effect on Children of Increasing the Length of Parents' Birth-Related Leave.

ISBN 9788778822437 (print); ISBN 9788778822444 (online).

WP 07-12 Tor Eriksson and Marie-Claire Villeval: Performance Pay, Sorting and Social Motivation.

ISBN 9788778822451 (print); ISBN 9788778822468 (online).

WP 07-13 Jane Greve: Obesity and Labor Market Outcomes: New Danish Evidence.

ISBN 9788778822475 (print); ISBN 9788778822482 (online).

2008:

WP 08-1 Sebastian Buhai, Miguel Portela, Coen Teulings and Aico van Vuuren: Returns to Tenure or Seniority ISBN 9788778822826 (print); ISBN 9788778822833 (online). 
WP 08-2 Flora Bellone, Patrick Musso, Lionel Nesta et Frédéric Warzynski: L'effet pro-concurrentiel de l'intégration européenne : une analyse de l'évolution des taux de marge dans les industries manufacturières françaises ISBN 9788778822857 (print); ISBN 9788778822864 (online).

WP 08-3 Erdal Yalcin: The Proximity-Concentration Trade-Off under Goods Price and Exchange Rate Uncertainty ISBN 9788778822871 (print); ISBN 9788778822888 (online)

WP 08-4 Elke J. Jahn and Herbert Brücker: Migration and the Wage Curve: A Structural Approach to Measure the Wage and Employment Effects of Migration ISBN 9788778822895 (print); ISBN 9788778822901 (online)

WP 08-5 Søren Harck: A Phillips curve interpretation of error-correction models of the wage and price dynamics

ISBN 9788778822918 (print); ISBN 9788778822925 (online)

WP 08-6 Elke J. Jahn and Thomas Wagner: Job Security as an

Endogenous Job Characteristic

ISBN 9788778823182 (print); ISBN 9788778823199 (online)

WP 08-7 Jørgen Drud Hansen, Virmantas Kvedaras and Jørgen UlffMøller Nielsen: Monopolistic Competition, International Trade and Firm Heterogeneity - a Life Cycle Perspective ISBN 9788778823212 (print); ISBN 9788778823229 (online)

WP 08-8 Dario Pozzoli: The Transition to Work for Italian University Graduates ISBN 9788778823236 (print); ISBN 9788778823243 (online)

WP 08-9 Annalisa Cristini and Dario Pozzoli: New Workplace Practices and Firm Performance: a Comparative Study of Italy and Britain ISBN 9788778823250 (print); ISBN 9788778823267 (online)

WP 08-10 Paolo Buonanno and Dario Pozzoli: Early Labour Market Returns to College Subjects

ISBN 9788778823274 (print); ISBN 9788778823281 (online) 